\title{
Music Teachers' Status of Participation in In-Service Training Programs and Their Expectations
}

\author{
Özlem Öztürk*a , Gökhan Öztürk ${ }^{\mathrm{b}}$
}

\begin{tabular}{l} 
Article Info \\
\hline DOI: 10.14686/buefad.458211 \\
\hline Article History: \\
Received 08.09.2018 \\
Accepted 24.12.2018 \\
Published $\quad 01.02 .2019$ \\
\hline Keywords: \\
Music teachers, \\
In-service training, \\
Expectations. \\
\hline Article Type: \\
Research article \\
\end{tabular}

\begin{abstract}
The aim of this research is to determine music teachers' participation status in inservice training programs and their expectations. This research, which was structured on survey model, was conducted with 48 music teachers in the center of Tokat city, Turkey. The data were obtained through personal data form and standardized interview form and analysed by means of descriptive analysis technique. According to the research results, the participation rate of music teachers in in-service training activities is low. Teachers tend to participate in the activities organized by the Provincial Directorate of National Education instead of the events organized by the Ministry of National Education. Activity topics are mainly aimed at the presentation of the curriculum. Music teachers demand that in-service training activities be organized in teaching methods, technology, Turkish music and instruction, guidance and personal development. The teachers' expectations with regard to the process of planning, implementation and evaluation of the activities are concentrated on the determination of the activity content by themselves, the presentation of the subjects by field experts from universities, the organization of the activities in the cities they work and during seminar seasons. Research results are discussed within the framework of the existing problems in the literature.
\end{abstract}

\section{Müzik Öğretmenlerinin Hizmetiçi Eğitim Programlarına Katılma Durumu ve Beklentileri}

\begin{tabular}{l} 
Makale Bilgisi \\
\hline DOI: $10.14686 /$ buefad.458211 \\
\hline Makale Geçmişi: \\
Geliş $\quad 08.09 .2018$ \\
Kabul $\quad 24.12 .2018$ \\
Published 01.02 .2019 \\
\hline Anahtar Kelimeler: \\
Müzik öğretmenleri, \\
Hizmetiçi eğitim, \\
Beklentiler. \\
\hline \\
\hline Makale Türü: \\
Araştırma makalesi \\
\end{tabular}

\section{$\ddot{\text { Öz }}$}

Bu araştırmanın amacı, müzik öğretmenlerinin hizmetiçi eğitim programlarına katılma durumunu ve beklentilerini saptamaktır. Tarama modeline göre yapılandırılan çalışma Türkiye'nin Tokat il merkezinde görevli 48 müzik öğretmeni ile yürütülmüştür. Veriler, kişisel bilgi formu ve standartlaştırılmış görüşme formuyla elde edilmiş ve betimsel analiz tekniğine göre çözümlenmiştir. Araştırma sonucuna göre, müzik öğretmenlerinin hizmetiçi eğitim etkinliklerine katılım oranı düşüktür. Öğretmenler Milli Eğitim Bakanlığı tarafından düzenlenen etkinlikler yerine İl Milli Eğitim Müdürlüğü tarafindan düzenlenen etkinliklere katılma eğilimindedir. Etkinlik konuları çoğunlukla öğretim programı tanıtımına yöneliktir. Müzik öğretmenleri; öğretim yöntemleri, teknoloji, Türk müziği ve öğretimi ile rehberlik ve kişisel gelişim konularında hizmetiçi eğitim etkinlikleri düzenlenmesini talep etmektedir. Öğretmenlerin etkinlikleri planlama, uygulama ve değerlendirme süreciyle ilgili beklentileri ise; etkinlik içeriğinin kendileri tarafından belirlenmesi, konuların üniversitelerden gelen alan uzmanları tarafindan sunulması, etkinliklerin görev yaptıkları şehirde ve seminer dönemlerinde düzenlenmesi yönünde yoğunlaşmaktadır. Araştırma sonuçları, alanyazında konuyla ilgili var olan sorunlar çerçevesinde tartışılmıştır.

*Corresponding Author: ozlem.ozturk@gop.edu.tr

a Dr., Tokat Gaziosmanpaşa University, Faculty of Education, Tokat/Turkey, https://orcid.org/0000-0003-1500-2968

${ }^{\mathrm{b}}$ Dr., Tokat Gaziosmanpaşa University, Faculty of Education, Tokat/Turkey, https://orcid.org/0000-0002-1667-3758 


\section{Introduction}

One of the basic components of the education systems is 'schools'. Schools are institutions where we can produce a reflection of the social order we want to achieve and transform society into larger scale and more resilient motives by shaping the minds accordingly (Dewey, 2004). Many factors, such as education policies, curricula, integration of technology into educational processes, socio-cultural changes etc. determine the quality of schools. In this sense, teacher is one of the most influential components in the realization of social ideals through schools.

Today's educational research concentrate on professional competencies and professional development of teachers. Teaching profession, which is a dynamic process and complex structure (Deneme \& Çelik, 2016; Küçükaydın, Sağır \& Kösterelioğlu, 2017), requires the updating and development of teacher competencies. The transforming socio-cultural structure, the current reforms in education, the expectations of new qualifications from the growing individual by the usual lifestyle dissolved in the context of globalization and individualization, the change of purpose and content in all branches by the spread of program development theories or the effect of technology on education (Kalyoncu, 2004) are essential bases that impose the improvement of teacher competencies.

It is necessary to constantly rearrange the system of teacher training with regard to structure, functioning, and curriculum in accordance with educational realities and current needs (Özden, 2010). Although pre-service training programs are revised in many countries in line with the trends, currents, and changing paradigms in certain periods, they lag behind rapid changes and fail to be effective in gaining teacher competencies (Deneme \& Çelik, 2016; Hugh, 2001; Phin, 2014; Seferoğlu, 2004; Uçar \& İpek, 2006; Yoo \& Lee, 2014). Therefore, current educational policies are being renewed in the direction of the search for systematic and sustainable solutions to fill the gap stemming from pre-service training and meet the needs and demands of rapidly changing education in the $21^{\text {st }}$ century. One of the main bases that guide these quests is in-service training of teachers (Azad, Tavakoli \& Ketabi, 2017; Raud \& Orehhova, 2017).

In-service training is a systematic practice designed to develop pedagogical practices and teaching skills, to solve challenges encountered in the professional process through scientific methods and in the light of socioeconomic facts, and to encourage teachers in promoting professional development (Eğitim-Bir Sen, 2004; Jan \& Hameed, 2016; OECD, 2016). In Turkey, the aims of in-service training organized by the Ministry of National Education (MoNE) are explained briefly according to the related regulation (Milli Eğitim Bakanlığı [MEB], 1994) as; a) to complete the deficiencies of pre-service training in terms of professional competence, b) to gain the knowledge, skills, and behaviors required by the innovations and developments in the field of education, c) to improve professional competence and understanding of the staff, d) to obtain integrity in the interpretation of Turkish national education policy, and, e) to provide unity in the implementation of principles and techniques of education. In-service training, which directly affects the quality of education systems and learning outputs, is a necessity for teachers today (Guskey, 2002; Jan \& Hameed, 2016; Raud \& Orehhova, 2017). Özyürek (1981) attributes this necessity upon the developments and advancements in science, society, schools, and teaching processes, and upon the expectations in teachers' fields of personal interest (Altınışık, 1996; Küçükahmet, 1998). In-service training provides teachers with the opportunity to acquire knowledge and skills in adapting to structural and cultural changes at schools (Nawab, 2017), to transform contemporary theories and models into educational activities, to operationalize educational reforms by ensuring coordination between theory and practice (Bush, 2007; Slingerland et al. 2017), and to create changes in classroom practices, attitudes, beliefs, and learning outcomes (Guskey, 2002).

Research reveal that in countries such as Finland, Canada, Singapore, where success has been achieved in education, professional development of teachers is put in the center, and the execution of in-service training is driven by an approach that prioritizes continuity and control (Abazaoğlu, 2014; Avrupa Komisyonu, 2013; Yoo \& Lee, 2014). By the beginning of teacher training in 1848, it is seen in Turkey that in-service training was experimented from time to time till a certain date. For example, it is known that an in-service training event was organized by Sati Bey, the director of İstanbul Darülmuallimin, in 1909. Usul-ü tedris, namely the method of teaching, was taught by specialists to two teachers (per province) selected from each province in this context (Ergun, Ergezer, Çevik \& Özdaş, 1999). Similarly, in 1926, in-service training was given under the name of 'holiday courses' in order to overcome the problems arising from the fact that primary school physical education, music, handicraft, and art lessons were instructed by teachers who did not receive subject matter training (Öztürk, 
2007). Notwithstanding the existence of these practices, in-service training programs in Turkey were officially included in the system for the first time in 1960. Today, in-service training activities for teachers are planned and carried out centrally by the Professional Development Support and Monitoring Department of the MoNE. Furthermore, provincial organizations were delegated the power by the Ministry of Education to arrange in-service training programs to solve the problems experienced in in-service training, to meet the training needs of teachers on-site and on time, and to put the activities into practice more effectively and widely (Bayram, 2010; Şahin, 1999). In recent years, it can be argued that in-service training has been made an effective structure thanks to the projects that are put into practice by the cooperation of the MoNE and private organizations (Abazaoğlu, 2014; Seferoğlu, 2004).

Despite these developments, studies in the literature show that various problems related to in-service training have been experienced in Turkey. One of the outstanding results in the studies is intentional/unintentional nonparticipation of teachers in the activities (European Commission, 2015). Nevertheless, it has been observed that the subjects of the activities are not taught using appropriate methods, techniques, tools and equipment in line with the scope of the teachers' needs, consequently, that the information and skills aimed at the programs are not gained to the participants (OECD, 2010; Özavcı \& Çelikten, 2017; Şahin, 2012), that a narrative-based and theoryweighted approach is pursued and practice is excluded (Gökmenoğlu, 2012; Karaca, 2010; Özen, 2006), that the participants' opinions are not taken in the pre- and post-activity period (Kızılarslan, 2012; Uçar \& İpek, 2006) and that the people chosen for the events are not determined according to objective criteria (Çiftci, 2008; Şahin, 2012). In the studies conducted by the MoNE, it is observed that professional development guidance was insufficient, everyone could not benefit sufficiently from in-service training due to the large number of staff, and the efficiency of in-service training and the level of motivation and organizational commitment of employees are not anticipated (MEB, 2008, 2009, 2017).

Today, the learning-teaching paradigm has shifted towards the autonomy of the learners and the role of the teacher has turned into a facilitator's and a manager's role in the learning process. Learning and teaching has evolved into a more learner-centric and more flexible structure, which is supported by new technologies (Raud \& Orehhova, 2017). The current transformation also directly affects music education and requires music teachers to use technology effectively in classroom teaching processes and to prefer technology-supported teaching methods. On the other hand, Kalyoncu (2004) reports that the image of the traditional music lesson has been going through a transformation, that the new targets, contents, and methodological developments demand from the music lesson and teacher beyond an activity of merely singing and playing an instrument, and that the functioning area of the music teacher has widened. In this context, one of the biggest challenges in the music teaching profession is teachers' competency to stay up-to-date on new practices and approaches in music education (Clements, 2010). In-service training is an effective method for the music teacher to be able to respond to the expectations and adapt to the current transformation. However, it is observed that the problems related to in-service training are also experienced in the music teaching profession. The results of the research indicate that music teachers have a low participation rate in the INSET activities. Besides, teachers find in-service training programs inadequate in quantity and quality. Teachers need in-service training in the areas of the planning, implementation, and evaluation of music lesson, education technologies, music teaching methods and techniques, accompaniment, composition, school instruments and educational music repertoire, relations among the school, the family, and the environment (Akdüz, 2006; Andırıcı, 2006; Çiftçi, 2008). It is reported that in-service training needs of music teachers cannot be generally met and that a new structuring in in-service training is required to ensure continuity in professional development (Çiftçi, 2008). It is considered according to the research results that music teachers are in need of inservice training and tend to participate; however, they have developed a negative attitude to attend the activities despite this expectation and tendency.

The success of in-service training depends on the identification of the needs and learning characteristics of teachers as the target audience, and the consideration of the basic principles of planning, implementation, and evaluation of in-service training activities (Guskey, 1991; Hakan et al. 2011; O'Sullivan, 2000). However, the current problems with in-service training programs organized for music teachers demonstrate that the principles of needs analysis are not taken into consideration in the process of program planning. In the light of these views, the aim of the study is to identify music teachers' status of participation in in-service training activities and to set forth their expectations. This study is expected to draw attention to the problem of professional development in 
the music teaching profession and to contribute to the practice of some plans that could positively affect participation rates through the suggestions presented. The following questions are addressed in the research:

1. What is the participation status of music teachers in the in-service training activities arranged by the Ministry of National Education and Provincial Directorate of National Education?

2. What is their participation status with regard to gender, institution of employment, graduate education, and professional seniority?

3. What are the subjects of in-service training participated?

4. What are their expectations regarding the content of in-service training activities?

5. What are their expectations regarding the processes of planning, implementation, and evaluation of inservice training activities?

\section{Method}

This study, which has a qualitative research characteristic, is structured according to single survey model. The main aim of the survey model is to reveal the emotions, thoughts, and opinions of individuals on any subject without any interference and to construct knowledge (Karasar, 2014). In this research, the participation status of music teachers in in-service training activities and their expectations are determined through teacher opinions.

\section{Study Group}

Survey studies cover large groups. In practice, however, it is practically impossible to examine the whole universe that constitutes the subject of the research. For this reason, data are collected by field survey conducted over a sample (Gökçe, 1992). In this context, the sample consisted of 48 music teachers working at the center of Tokat city, and in public schools. Permission for the study group from the relevant institution has been obtained in advance. Personal characteristics of the study group are exhibited in Table 1.

Table 1. The Distribution of the Study Group According to Personal Characteristics

\begin{tabular}{llll}
\hline Personal Characteristics & & f & \% \\
\multirow{2}{*}{ Gender } & Female & 24 & 50,0 \\
\cline { 2 - 4 } & Male & 24 & 50,0 \\
\hline \multirow{4}{*}{ Institution of Employed } & Secondary School & 20 & 41,7 \\
\cline { 2 - 4 } & Fine Arts High School & 13 & 27,1 \\
\cline { 2 - 4 } & High School & 9 & 18,8 \\
\cline { 2 - 4 } Graduate Education & Special Education Institution & 6 & 12,5 \\
\hline \multirow{4}{*}{ Professional seniority } & Yes & 12 & 25,0 \\
\cline { 2 - 4 } & No & 36 & 75,0 \\
\hline & 6-10 years & 6 & 35,5 \\
\cline { 2 - 4 } & $11-15$ years & 17 & 35,4 \\
\cline { 2 - 4 } & 16 and above years & 17 & 16,7 \\
\hline
\end{tabular}

According to Table $1,50 \%$ of the teachers are female and $50 \%$ are male. According to the same table, $41,7 \%$ of the teachers are in secondary schools, 27,1\% in Fine Arts High Schools, 18,8\% in high schools, and 12,5\% in special education institutions. On the other hand, it is seen that $25 \%$ of teachers received graduate education, whereas the $75 \%$ majority did not. According to the professional seniority, $12,5 \%$ of the teachers have $1-5$ years, $35,4 \%$ have $6-10$ years, $35,4 \%$ have $11-15$ years, $16,7 \%$ have 16 and above years of professional experience.

\section{Data Gathering}

The study data were collected through interview technique. Interview is the most important data gathering tool for descriptive studies aimed at deciphering the lives, perceptions of individuals and the common meanings ascribed to these by them in relation to certain subjects. The experiences gained as a result of individual or collective interviews are defined and the themes are revealed (Patton, 2014). Personal information form and standardized open-ended interview form were used to obtain the study data. There were questions in the personal information form relating to the gender of the teachers, the institution of employment, the status of graduate education, professional seniority, participation status in in-service training activities, and the subjects of the 
activities attended. The questions in the interview form had two different structures. In the form, there were ordinal and open-ended questions aimed at determining the teachers' expectations and rationales related to the content of in-service training and to the planning, implementation, and evaluation processes of activities. Below are some sample questions from the interview form.

Table 2a. Sample Question Prepared to Determine the Expectations Regarding the Contents of the Activities

\begin{tabular}{lll}
\hline Field of Expectation & Question & Expectations \\
\hline \multirow{3}{*}{ Content of the activities } & \begin{tabular}{l} 
Which subjects would you like to be included in the in-service training \\
\cline { 2 - 3 }
\end{tabular} & activities? (Specify according to the order of significance!) \\
\cline { 2 - 3 } & Please explain the reason for your order of preference. & 3 \\
\hline
\end{tabular}

Table 2b. Sample Question Prepared to Determine the Expectations Regarding the Formal Structure of the Activities

\begin{tabular}{|c|c|c|c|}
\hline Field of Expectation & Comments & $\begin{array}{l}\text { Whe } \\
\text { acti }\end{array}$ & $\begin{array}{l}\text { should in-service training } \\
\text { ies be held? }\end{array}$ \\
\hline \multirow{6}{*}{$\begin{array}{l}\text { Planning, } \\
\text { implementation, and } \\
\text { evaluation of the } \\
\text { activities }\end{array}$} & \multirow{5}{*}{$\begin{array}{l}\text { Sort the options on the list on the right according to } \\
\text { your need. ( } 1 \text { being the highest priority!) }\end{array}$} & $\ldots .$. & During summer holiday \\
\hline & & $\ldots .$. & During semester holiday \\
\hline & & $\ldots \ldots$ & During education season \\
\hline & & $\ldots \ldots$ & During seminar season \\
\hline & & $\ldots \ldots$ & Other (Please explain!)........... \\
\hline & $\begin{array}{l}\text { Please explain the rationale for the prioritization of } \\
\text { your requirements. }\end{array}$ & & \\
\hline
\end{tabular}

\section{Data Analysis}

The study data were analyzed through descriptive analysis technique. Descriptive analysis is mostly applied in cases where the conceptual framework of the research is clearly defined beforehand. Further, in qualitative studies it is possible to reduce written data to the numbers at a certain level. Numerical analysis is the converting of study data into numbers. The main purpose of digitizing qualitative data is; to increase reliability, to reduce bias, to allow comparison between data, and to allow re-examining, again on over a large sample, the results of a small scale research or a case study (Yıldırım \& Şimşek, 2006). In this research, frequency analyses and percentage calculations are used for the analysis of the data.

\section{Validity and Reliability}

In qualitative research, validity secures reliability to a great extent, and the importance given to validity should at the same time be perceived as a measure taken to ensure reliability. Detailed reporting of the data gathered and the researcher's explanations of how he/she has arrived at the results are among the most important criteria of validity in qualitative research (Yıldırım \& Şimşek, 2006). In order to ensure validity in this study, a field survey was conducted on the subject, a conceptual framework was built, and the interview form was prepared according to the conceptual framework. The opinions of two experts in the field of educational sciences have been consulted to determine the clarity of the interview form and its suitability for the purpose of the study. The final version of the form was shaped by making necessary revisions in line with incoming feedbacks. The data obtained were organized, analyzed simultaneously, and compared thereafter by the authors.

The data were interpreted through quantification and by the support of tabulation in the results section, and some opinions of the teachers were used directly to underpin interpretations. In qualitative studies, 'participant confirmation' is an important method for reliability. In this approach, it is aimed at ensuring reliability by minimizing the loss of data through an open-ended question, where participants can convey their perceptions and/or experiences that they think are relevant but not addressed by the standard questions.

\section{Results}

This section includes the participation status of the music teachers in in-service training activities, the topics of the organized activities, and the expectation of the teachers from in-service training. In the presentation of the findings, the abbreviation 'MoNE' stands for the Ministry of National Education, 'PDoNE' stands for the Provincial Directorate of National Education, and 'INSET' stands for in-service training. 
Results related to the $1^{\text {st }}$ and $2^{\text {nd }}$ sub-problem: Participation status of music teachers in INSET activities and frequency distribution according to gender, institution of employment, graduate education, and professional seniority

Table 3. The Frequency Distribution of the Participation Status of Music Teachers in the Activities Held by the MoNE and the PDoNE

\begin{tabular}{lcccc}
\hline \multirow{2}{*}{ Participation Status } & \multicolumn{2}{c}{ Yes } & \multicolumn{2}{c}{ No } \\
\cline { 2 - 5 } & f & $\mathbf{\%}$ & $\mathbf{f}$ & $\mathbf{\%}$ \\
\hline I have participated in the activities held by the MoNE & 7 & 14,6 & 41 & 85,4 \\
\hline I have participated in the activities held by the PDoNE & 12 & 25,0 & 36 & 75,0 \\
\hline I have participated in the activities held by the MoNE and/or PDoNE & 17 & 35,4 & 31 & 64,6 \\
\hline
\end{tabular}

According to Table 3,14,6\% of the music teachers participated in the activities organized by the MoNE and $85,4 \%$ majority did not participate in any activities organized by the Ministry. It is also observed that $25 \%$ of the teachers participated in the activities organized by the PDoNE and $75 \%$ majority did not participate in any activity organized by the Directorate. On the other hand, although 35,4\% of the teachers attended the activities arranged by the MoNE and/or the PDoNE, 64,6\% did not participate in any activity organized by the two institutions. Findings indicate that music teachers have a low participation rate in the INSET activities. It can be argued that teachers are more inclined to participate in the events organized by the PDoNE instead of the MoNE. This tendency can be attributed to the fact that the PDoNE activities are arranged in the city where teachers live and are easily accessible.

Table 4. The Distribution of Participation Status according to Gender, Institution of Employment, Graduate Education, and Professional Seniority

\begin{tabular}{|c|c|c|c|c|c|}
\hline \multirow{2}{*}{ Personal Characteristic } & & \multicolumn{2}{|c|}{ Participated } & \multicolumn{2}{|c|}{ Not Participated } \\
\hline & & $\mathbf{f}$ & $\%$ & $\mathbf{f}$ & $\%$ \\
\hline \multirow{2}{*}{ Gender } & Female & 6 & 25,0 & 18 & 75,0 \\
\hline & Male & 11 & 45,8 & 13 & 54,2 \\
\hline \multirow{4}{*}{ Institution Employed } & Primary School & 7 & 40,0 & 13 & 60,0 \\
\hline & Secondary School & 2 & 22,2 & 7 & 77,8 \\
\hline & Fine Arts High School & 4 & 30,8 & 9 & 69,2 \\
\hline & Special Education Institution & 4 & 66,7 & 2 & 33,3 \\
\hline \multirow{2}{*}{ Graduate Education } & Yes & 3 & 25,0 & 9 & 75,0 \\
\hline & No & 14 & 38,9 & 22 & 61,1 \\
\hline \multirow{4}{*}{ Professional Seniority } & $1-5$ years & 2 & 33,3 & 4 & 66,7 \\
\hline & $6-10$ years & 3 & 17,6 & 14 & 82,4 \\
\hline & $11-15$ years & 9 & 52,9 & 8 & 47,1 \\
\hline & 16 and above years & 3 & 37,5 & 5 & 62,5 \\
\hline
\end{tabular}

According to Table 4, the participation rate of female music teachers in the INSET activities (25\%) is lower than that of male teachers $(45,8 \%)$. When the findings related to the institution of employment is examined, it is observed that the attendance rates of music teachers in secondary education $(22,2 \%)$ and Fine Arts High Schools $(30,8 \%)$ are lower than those in primary education $(40 \%)$ and special education institutions $(66,7 \%)$. According to these results, it is noteworthy that the attendance rate of music teachers in special education institutions $(66,7 \%)$ is higher than teachers in other institutions. According to another finding, there is also a difference in the participation rates of teachers with and without a graduate education. The participation rate of teachers who have a master degree $(25 \%)$ is lower than that of the teachers without a master degree $(38,9 \%)$. In the case of professional seniority, it is observed that the participation rate of the teachers who have experience between 6-10 years is lowest $(17,6 \%)$, that the participation rate of teachers with $1-5$ years $(33,3 \%)$ and 16 and more years $(37,5 \%)$ are again low and close to each other, and that the participation rate of the teachers with 11-15 years of experience $(52,9 \%)$ are higher than the other groups. According to this finding, it can be said that participation in activities in the first 10 years of the profession is at a lower level. On the other hand, the fact that $62,5 \%$ of teachers who are experienced 16 or more years do not participate in any activity is thought-provoking. In addition, the proportion of teachers (75\%) who received graduate education but did not participate in any INSET activities is noteworthy. This can be interpreted in a way that INSET activities do not attract the interest of the teachers who received graduate education or that the activities do not meet their expectations. 


\section{Results related to the $3^{\text {rd }}$ sub-problem: The subject of the INSET activities attended by the music teachers}

Table 5. The Distribution according to the Last Activity Attended by the Music Teachers

\begin{tabular}{llll}
\hline Organizing Institution & Topics & f & Total \\
\hline \multirow{4}{*}{ MoNE } & Promotion of music lesson curriculum & 4 & \\
\cline { 2 - 3 } & Membership to Turkish folk music jury & \multirow{2}{*}{10} \\
\cline { 2 - 3 } & Book review & 2 \\
\cline { 2 - 3 } & Orff-Schulwerk & 2 \\
\cline { 2 - 3 } PDoNE & Music education for highly talented students & 1 \\
& Promotion of music lesson curriculum & 1 \\
\cline { 2 - 3 } & Problems of teaching profession and solutions & 3 \\
\cline { 2 - 3 } & Orff-Schulwerk & 1 & 2 \\
\hline
\end{tabular}

According to Table 5, the topic of the INSET events organized by the MoNE and the PDoNE are mainly ( $\mathrm{f}=4$ and $\mathrm{f}=3$ ) the promotion of the curriculum of music lesson. Apart from this, it is observed that the MoNE organized activities on the subjects of jury membership for Turkish folk music ( $f=2)$, book review ( $f=2$ ), Orff-Schulwerk training $(\mathrm{f}=1)$, music education for gifted students $(\mathrm{f}=1)$, and that the PDoNE arranged activities on the subjects of the problems of teaching profession and solutions $(\mathrm{f}=2)$ and Orff-Schulwerk training $(\mathrm{f}=1)$. According to the findings, it can be said that INSET activities are mostly preferred by the MoNE and the PDoNE for the purpose of promoting updated/renewed educational programs, whereas the contents for teachers' professional and personal development are not planned in the expected direction.

\section{Results related to the $4^{\text {th }}$ and $5^{\text {th }}$ sub-problem: INSET expectations of the music teachers}

Table 6. The Distribution of Expectations regarding the Content of the Activities

\begin{tabular}{|c|c|c|}
\hline $\begin{array}{l}\text { Content } \\
\text { Expectations }\end{array}$ & f & Excerpts from Teacher Opinions \\
\hline $\begin{array}{l}\text { Music/Educational } \\
\text { Technologies }\end{array}$ & 33 & $\begin{array}{l}\text { "Technology, technology, technology, this is the era of technology! The students are } \\
\text { technological! Everything must be associated with technology" }\end{array}$ \\
\hline $\begin{array}{l}\text { Music Teaching } \\
\text { Methods }\end{array}$ & 30 & $\begin{array}{l}\text { "General music teaching methods are not effective in populous classrooms. Different } \\
\text { methods should be introduced in in-service trainings. But, the promotions should be supported } \\
\text { with best practices" }\end{array}$ \\
\hline $\begin{array}{l}\text { School } \\
\text { Instruments and } \\
\text { Accompaniment }\end{array}$ & 28 & $\begin{array}{l}\text { "I often teach melodica now. When I want to accompany a song I teach, I have difficulty } \\
\text { even though my harmony knowledge is enough" } \\
\text { "I am having difficulty preparing a program for important days and weeks. If I can teach } \\
\text { different instruments, more colourful events can be prepared" }\end{array}$ \\
\hline $\begin{array}{l}\text { Turkish Music and } \\
\text { Training }\end{array}$ & 24 & $\begin{array}{l}\text { "I am having difficulty in teaching maqam music because I, myself, do not have a full } \\
\text { grasp. I want to learn a Turkish music instrument" }\end{array}$ \\
\hline Guidance & 20 & $\begin{array}{l}\text { "Student profiles are very different; we are experiencing disciplinary problems both } \\
\text { within the classroom and outside the classroom arising from the free dress regulation, } \\
\text { crowded classes, and family. It's harder to keep students under control compared to the past. } \\
\text { Effective classroom management, communication, guidance, etc. seminars for teachers should } \\
\text { be given" }\end{array}$ \\
\hline $\begin{array}{l}\text { Personal } \\
\text { Development }\end{array}$ & 18 & $\begin{array}{l}\text { "Professional development should not only be perceived theoretically, activities that are } \\
\text { informative and encouraging for graduate study should be organized" } \\
\text { "Seminar topics are usually based on narrative, there are no topics related to our } \\
\text { personal development, and that does not interest me. For example, activities such as effective } \\
\text { speaking and communication, foreign language, project development can be organized" }\end{array}$ \\
\hline $\begin{array}{l}\text { Music Lesson } \\
\text { Curricula }\end{array}$ & 4 & $\begin{array}{l}\text { "The curriculum is an important guide for me. I think that I can teach an effective course } \\
\text { if I master the program. I also want to be aware of the latest update on the program" }\end{array}$ \\
\hline
\end{tabular}

According to Table 6, music teachers mostly $(\mathrm{f}=33$ ) want music/educational technology topics to be included in the activities. This demand is followed by music teaching methods $(\mathrm{f}=30)$, and school instruments and accompaniment $(\mathrm{f}=28)$. Teachers, furthermore, demand activities on the subjects of Turkish music and training $(\mathrm{f}=24)$ and guidance $(\mathrm{f}=20)$ as well. It is observed that the general tendency in expectations is concentrated on the field subjects. It should be noted that although Table 5 includes teachers' demand for activities regarding music lesson curricula $(\mathrm{f}=4)$, it should be underlined that program promoting activities were not requested by most 
teachers when compared to other topics. This can be attributed to the concentration of activities attended by the teachers mostly on program promotion subjects, as can also be seen in Table 5.

Table 7. The Distribution of Expectations related to the Planning, Implementation, and Evaluation of the Activities.

\begin{tabular}{|c|c|c|c|}
\hline $\begin{array}{l}\text { Field of } \\
\text { Expectation }\end{array}$ & Opinions & $\mathbf{f}$ & Excerpts from Teacher Opinions \\
\hline \multirow{3}{*}{$\begin{array}{l}\text { Method of } \\
\text { Determining } \\
\text { Subject }\end{array}$} & My views should be taken & 42 & \multirow{3}{*}{$\begin{array}{l}\text { "My 12th year in my profession. Ijoined seminars } 4 \text { times } \\
\text { but nobody came and asked my opinion. It does not matter } \\
\text { when and where, I am expecting an approach or a method } \\
\text { that considers my expectations" } \\
\text { "The number of events is very small and I think it's } \\
\text { boring. In this era where technology use is widespread, the } \\
\text { ministry should focus on distance in-service training } \\
\text { method" }\end{array}$} \\
\hline & Universities should determine & 18 & \\
\hline & MoNE/PDoNE should determine & 6 & \\
\hline \multirow{3}{*}{ Trainer(s) } & $\begin{array}{l}\text { Lecturers from universities } \\
\text { should carry out }\end{array}$ & 40 & \multirow{3}{*}{$\begin{array}{l}\text { "The teaching of lecturers from universities is different } \\
\text { and enjoyable" } \\
\text { "I do not think that the coordinator teacher who makes } \\
\text { the program promotion does have a full grasp of the } \\
\text { program" }\end{array}$} \\
\hline & $\begin{array}{l}\text { Universities and the MoNE } \\
\text { should carry out in partnership }\end{array}$ & 12 & \\
\hline & DoNE should carry out & 8 & \\
\hline \multirow{3}{*}{ City } & $\begin{array}{l}\text { should be held at my place } \\
\text { ty }\end{array}$ & 33 & \multirow{3}{*}{$\begin{array}{l}\text { "The financial support of the MoNE is limited, I am } \\
\text { spending my own budget when I go to another city for a } \\
\text { seminar. I think that the budget should be increased or it } \\
\text { should be held inthe city where I am on duty" }\end{array}$} \\
\hline & It should be held on seaside & 6 & \\
\hline & $y^{2}$ & 4 & \\
\hline \multirow{3}{*}{ Time } & $\begin{array}{l}\text { hould be held during seminar } \\
\text { sson }\end{array}$ & 32 & \multirow{3}{*}{$\begin{array}{l}\text { "People cannot concentrate in the events during holidays. } \\
\text { I think seminar periods are ideal for in-service training. We } \\
\text { do not actually do anything in this period. If it is done during } \\
\text { the seminar period, it will be more productive and more } \\
\text { participatory" }\end{array}$} \\
\hline & $\begin{array}{l}\text { should be held during teaching } \\
\text { rm }\end{array}$ & 10 & \\
\hline & should be held in holiday time & 9 & \\
\hline \multirow{3}{*}{ Duration } & ould last 1 week & 28 & \multirow{3}{*}{$\begin{array}{l}\text { "Teaching time is more effective if it is done once a week } \\
\text { or one week in each semester" }\end{array}$} \\
\hline & ould last 5 days & 16 & \\
\hline & & 6 & \\
\hline \multirow{3}{*}{ Place } & ould be held in music class & 2 & \multirow{3}{*}{$\begin{array}{l}\text { "First of all, courses should be given in the field of music } \\
\text { and activities should be held in field-specific halls" }\end{array}$} \\
\hline & Should be held in wide halls & 14 & \\
\hline & Should be held at universities & 12 & \\
\hline \multirow{3}{*}{ Accommodation } & d rather stay at home & 24 & \multirow{3}{*}{$\begin{array}{l}\text { "If it is held in the city that I live, I will stay at home and } \\
\text { will not have trouble paying for accommodation" }\end{array}$} \\
\hline & I'd rather stay at a hotel & 14 & \\
\hline & I'd rather stay at a guesthouse & 4 & \\
\hline \multirow{3}{*}{$\begin{array}{l}\text { Measurement } \\
\text { and Evaluation }\end{array}$} & No exam should be applied & 17 & \multirow{3}{*}{$\begin{array}{l}\text { "When I am judged by paper and pen, I feel strange and } \\
\text { nervous" } \\
\text { "There should be an academic incentive system as in } \\
\text { universities. Examinations should be done through the } \\
\text { module, and incentives should be given according to the } \\
\text { results of the exam" }\end{array}$} \\
\hline & $\begin{array}{l}\text { should be done on electronic } \\
\text { environment }\end{array}$ & 15 & \\
\hline & should be done as oral evaluation & 10 & \\
\hline
\end{tabular}

According to the findings presented in Table 7 and the findings achieved by ordering according to the preference area with the highest frequency status, the music teachers demand that the topics of the INSET be determined by themselves $(\mathrm{f}=42)$ and that the topics be presented by university lecturers $(\mathrm{f}=40)$. On the other hand, a significant majority of the teachers state that the activities should be organized in the city where they work $(\mathrm{f}=33)$ and during seminar seasons $(\mathrm{f}=32)$. More than half of the teachers, however, expect the activities to last for one week ( $\mathrm{f}=28)$ and to be performed in music halls/rooms $(\mathrm{f}=26)$. According to the table, half of the teachers want to stay at their home during the activity period $(\mathrm{f}=24)$. For the last finding, teachers' opinions against measurement and evaluation are notable $(\mathrm{f}=17)$, as well. A significant part of the teachers who think that evaluation should be done prefer electronic environment $(\mathrm{f}=15)$, while others prefer oral evaluation $(\mathrm{f}=10)$. 


\section{Conclusion and Recommendations}

In this study, which is conducted in order to determine music teachers' participation status and expectations regarding in-service training (INSET) programs, it is found that the participation level of the teachers in the activities is low, and that there are various expectations regarding the planning, implementation, and evaluation process of the activities.

The research revealed that $64,6 \%$ of the music teachers did not participate in any professional development activities organized by the MoNE or the PDoNE. This result is in agreement with the results of the other research on the subject. In a comprehensive survey conducted all across Turkey, Çiftci (2008) disclosed that $65,7 \%$ of the music teachers did not participate in the INSET activities. Similarly, Andırıc1 (2006) found that 91,3\% of the music teachers in İstanbul and Akdüz (2006) determined in a study on a sample from the city of Ankara that $40 \%$ of the music teachers did not participate in any professional development activities related to their branches. Similarly, according to a recent report, in Turkey, classroom teachers' and branch teachers' rates of participation in professional development activities are quite lower compared to the average of the countries participating in TIMSS (MEB, 2016).

According to another finding, the events organized by the MoNE and the PDoNE are mainly aimed at promoting the curriculum. On the other hand, music teachers demand INSET primarily on the use of technology and teaching methods in the field of music and then school instruments and accompaniment, Turkish music and training, and guidance and personal development. It is observed that this finding is in agreement with the results in the literature. For example, in a survey conducted by the MoNE (MEB, 2008), it was revealed that the teachers' expectations from INSET were distributed among 68 subjects and the lowest demand was for 'the promotion of changing programs'. According to research conducted by the MoNE, the vast majority of teachers expected activities to be organized on new approaches in education, the use of new educational technologies, the methods and techniques of teaching-learning, methods of coping with stress, classroom communication and interaction, student recognition techniques, classroom management models, and human relations (MEB, 2008, 2013, 2014). It is determined in the research conducted in the field of music that the teachers have firstly INSET requirements on the subjects of technology and teaching methods in music education (Akdüz, 2006; Çiftci, 2008). On the basis of results of the current research, it can be argued that music teachers have not participated in the INSET activities at the expected rate, activity topics have not met teacher expectations and these two basic problems have been lasting in the music teaching profession for a long time.

The last finding of the study reveals that the teachers have expectations regarding the planning, implementation, and evaluation process of the INSET activities. Almost all the music teachers expect to be consulted at the stage of specification of activity subjects and that the content of the activities to be presented by field specialist lecturers from universities. In addition, the teachers request that the activities are organized in their home city and during seminar seasons, last one week, no examinations are held in the measurement and evaluation stage, or examinations are held in electronic environments. It is possible to support these results with the results of existing studies in the literature (Gökmenoğlu, 2012; Günbayı \& Taşdöğen, 2012; Özavcı \& Çelikten, 2017; Satmaz \& Gencel, 2016; Şahin, 2012). The authors of this study consider significant the expectations of music teachers that their views should be taken during the planning of the INSET programs. Professional development is as personal as it is institutional and must be managed by the individual to be effective (Browell, 2000, cited in Bush, 2007). Determination of topics in line with the needs of teachers will encourage the participation of teachers, increase their motivation, and create a change that can be transferred to the classroom (Colwell, 1996/1997, cited in Bush; 2007).

Teachers pass through various stages in their professional lives and have different interests and needs at each stage. From the moment entering upon the career, teacher's interest and curiosity concentrate at certain points at certain times, and such concentrations require the application of different in-service training models (Saban, 2000). On the other hand, their beliefs are the things that attract teachers to professional development (Guskey, 2002; Şenel, 2014). However, professional development programs often fail, notwithstanding many factors, especially because they do not take into account factors that motivate teachers for professional development and the processes in which teachers typically go through a change (Guskey, 1986). The results of this research and other studies in the literature show that the situation is also valid for Turkey. Teachers in Turkey think that professional development is not adequately valued (Ceylan \& Özdemir, 2016) and it comes out that music teachers' 
expectations, as of other branch teachers, are not considered at satisfactory levels by the concerned units. This situation justify the opinion that 'a healthy, effective, and organized in-service training policy for teachers does not exist' (Budak \& Demirel, 2003; Karaca, 2010; Uçar \& İpek, 2006) and 'it has become inevitable to make a new arrangement regarding the planning, implementation, and evaluation of in-service training activities' (Şahin, 1999). It is evident that professional development programs that are planned without due attention to teachers' needs and without links to practice will not be effective. For this reason, it is believed that the problems experienced about INSET should be intervened urgently and effectively by the MoNE, and that there is a need for a radical change in professional development. Some suggestions can be made in the light of these views:

Teacher population is large and the budget for professional development is limited in Turkey (MEB, 2009; Seferoğlu, 2004), which is one of the most important problems in the INSET planning process. Further, there are music teachers in the education system who have not participated in INSET activities, although they have been on duty for many years. Therefore, the research findings suggest the inclusion of the universities within the process, the establishment of 'In-service Training Institutes' by the corporation of the MoNE and the universities, and the stipulation of the arrangement of professional development activities by every university that has a faculty of education.

Teachers give due consideration to professional development and believe that in-service training activities make beneficial contributions to their organizational and individual developments (Gültekin \& Çubukçu, 2008; Özen, 2006; Pepeler, Murat \& Akmençe, 2016; Sarıgöz, 2011; Satmaz \& Gencel, 2016); however, they are in a negative attitude towards in-service training (Karasolak, Tanrıseven \& Konokman, 2013). In recent years, the INSET needs of teachers are being determined by means of the modules applied by the MoNE and the participant teachers are asked to evaluate the activities within this context. It could be said depending on the results of the research scrutinized in this study above that this application is in point but not effective. It should be born in mind that one of the primary ways of increasing the organizational commitment of teachers is to increase their satisfaction level with regard to meeting their expectations from the organization (Türk Eğitim Derneği [TED], 2014). For better outcomes, all teachers should be included in the system by the Department of Professional Development Support and Monitoring in the MoNE through the installation of a more functional and powerful informatics network, and a distinct unit should be established where the demands and evaluations will be tracked and analyzed meticulously.

This study demonstrated that music teachers are inclined to attend the activities which are held by the PDoNE instead of the MoNE. Seminars at the local level contribute more to teachers, and seminar success and the inservice training approach of the Provincial Directorate of National Education are closely related (Şahin, 2012). In this sense, participation can be at higher rates if the activities are held in their cities of work and by the Provincial Directorate, particularly when economic factors are considered. Thus, a well-directed policy could include the broadening of the INSET powers delegated to the local authorities in 1993, reporting of the activities arranged at the provincial level, and sharing of the reports with those concerned.

There is movement and accompaniment in the nature of music and in its teaching process. Music teachers demand for practicable INSET activities, instead of theoretical presentations, that they can put into practice during in-class teaching processes. Besides, it is a fact that the workshops performed with group teachers in the seminars held at the beginning and end of the education-teaching term are found more beneficial by teachers (Pepeler et al. 2016). For this reason, the planning of best practice activities with practical content for music teachers by the academics working in departments of music teacher training program and the delivery of these programs with active participation methods during seminar seasons should be put into practice.

There is a need for up-to-date and thorough studies that draw attention to music teachers' expectations for professional development. A limited number of research studies in the literature present starting points for prospective studies and are valuable in this regard. Researchers who have an interest in the subject should develop practicable projects, along with theoretical studies, that can meet teachers' expectations, and participatory activities, such as workshops, for INSET should be arranged accordingly. 


\title{
Müzik Öğretmenlerinin Hizmetiçi Eğitim Programlarına Katılma Durumu ve Beklentileri
}

\begin{abstract}
Giriş
Eğitim sistemlerinin temel bileşenlerinden biri okullardır. Okullar, gerçekleştirmek istediğimiz toplumsal düzenlerin bir yansımasını üretebileceğimiz ve zihinleri buna göre şekillendirerek toplumu daha geniş ölçekli ve daha direngen motiflere dönüştürebileceğimiz kurumlardır (Dewey, 2004). Eğitim politikaları, öğretim programları, teknolojinin eğitim-öğretim süreçleriyle bütünleşmesi, sosyo-kültürel değişimler vb. birçok etken okulların niteliğini belirlemektedir. Bu anlamda, toplumsal ideallerin okullar üzerinden hayata geçirilmesindeki en etkili bileşenlerden biri de öğretmendir.
\end{abstract}

Günümüz eğitim araştırmaları, öğretmenlerin mesleki yeterlikleri ve mesleki gelişimleri üzerine yoğunlaşmıştır. Dinamik bir süreç ve karmaşık bir yapı olan öğretmenlik mesleği (Deneme ve Çelik, 2016; Küçükaydın, Sağır ve Kösterelioğlu, 2017) öğretmen yeterliklerinin güncellenmesini ve geliştirilmesini zorunlu kılmaktadır. Dönüşüm geçiren sosyo-kültürel yapı, eğitim alanındaki güncel reformlar, küreselleşme ve bireyselleşme bağlamında çözülen alışılmış yaşam biçimlerinin yetişecek bireyden yeni nitelikler beklentisi, program geliştirme teorilerinin yaygınlık kazanmasıyla tüm branşlardaki amaç ve içeriklerin değişmesi ya da teknolojinin eğitime olan etkisi (Kalyoncu, 2004) öğretmen yeterliklerinin geliştirilmesini zorunlu kılan temel dayanaklardır.

Öğretmen yetiştirme sistemini yapı, işleyiş ve öğretim programı olarak eğitim gerçekleri ve güncel ihtiyaçlar doğrultusunda sürekli yeniden düzenlemek gerekir (Özden, 2010). Çünkü, özellikle hizmet öncesi eğitim programları, çoğu ülkede, belli dönemlerdeki eğilimler, akımlar ve değişen anlayışlar doğrultusunda yenilenmesine karşın, hızlı değişimlerin gerisinde kalmakta, öğretmen yeterliklerinin kazandırılmasında etkili olamamaktadır (Deneme ve Çelik, 2016; Hugh, 2001; Phin, 2014; Seferoğlu, 2004; Uçar ve İpek, 2006; Yoo ve Lee, 2014). Bu nedenle, güncel eğitim politikaları, hizmet öncesi eğitimden kaynaklanan açığ kapatmak ve 21 . yüzyılın hızla değişen eğitime ilişkin ihtiyaç ve taleplerine cevap verebilmek için sistemli ve sürdürülebilir çözüm arayışları doğrultusunda yenilenmektedir. Bu arayışlara yön veren temel dayanaklardan biri de öğretmenlerin hizmetiçi eğitimleridir (Azad, Tavakoli ve Ketabi, 2017; Raud ve Orehhova, 2017).

Hizmetiçi eğitim, eğitimsel uygulamaları ve öğretim becerilerini geliştirmek, mesleki süreçte karşılaşılan güçlükleri bilimsel yöntemlerle çözmek ve öğretmenleri mesleki gelişime özendirmek amacıyla tasarlanan sistemli uygulamalardır (Eğitim-Bir Sen, 2004; Jan ve Hameed, 2016; OECD, 2016). Ülkemizde, Milli Eğitim Bakanlığı (MEB) tarafından düzenlenen hizmetiçi eğitimin amaçları, ilgili yönetmeliğe (MEB, 1994) göre özetle; a) mesleki yeterlilik açısından hizmet öncesi eğitimin eksikliklerini tamamlamak, b) eğitim alanındaki yeniliklerin, gelişmelerin gerektirdiği bilgi, beceri ve davranışları kazandırmak, c) personelin mesleki yeterlik ve anlayışlarını geliştirmek, d) Türk milli eğitim politikasını yorumlamada bütünlük kazandırmak, e) eğitime ait temel prensip ve teknikleri uygulamada birlik sağlamak şeklinde açıklanmıştır. Eğitim sistemlerinin niteliğini ve öğrenme çıktılarını doğrudan etkileyen hizmetiçi eğitim, günümüzde öğretmenler için bir zorunluluktur (Guskey, 2002; Jan ve Hameed, 2016; Raud ve Orehhova, 2017). Bu zorunluluk; bilimde, toplumda, okullarda ve öğretim süreçlerinde ortaya çıkan gelişim ve ilerlemeler ile öğretmenlerin kişisel ilgi alanlarındaki beklentilerine dayanmaktadır (Altınışık, 1996; Küçükahmet, 1998). Hizmetiçi eğitim öğretmenlere, okullardaki yapısal ve kültürel değişimlere uyum sağlama konusunda bilgi ve beceri kazandırma (Nawab, 2017), çağdaş teorileri ve modelleri eğitim etkinliklerine dönüştürme, teori ile pratik arasındaki eşgüdümü sağlayarak eğitim reformlarına işlevsellik kazandırma (Bush, 2007; Slingerland ve diğerleri, 2017) ve sınıf içi pratiklerde, tutumlarda, inançlarda ve öğrenme çıktılarında değişiklik yaratma firsatı sunar (Guskey, 2002).

Araştırmalar, Finlandiya, Kanada, Singapur gibi eğitimde başarıyı yakalayan ülkelerde öğretmenin mesleki gelişiminin merkeze alındığını, hizmetiçi eğitimin sürekliliği ve denetimi ön plana alan bir yaklaşımla yürütüldüğünü ortaya koymaktadır (Abazaoğlu, 2014; Avrupa Komisyonu, 2013; Yoo ve Lee, 2014). Ülkemizde de, 1848 yllında başlayan öğretmenlik eğitimiyle birlikte hizmetiçi eğitimin belli bir tarihe kadar zaman zaman denendiği görülmektedir. Örneğin, 1909 yılında İstanbul Darülmuallimin müdürü Sati Bey tarafindan bir hizmetiçi eğitim etkinliği düzenlendiği bilinmektedir. Her vilayetten seçilen iki öğretmene uzmanlar tarafindan usul-ü tedris yani öğretim yöntemi dersi verilmiştir (Ergun, Ergezer, Çevik ve Özdaş, 1999). Benzer şekilde 1926 yılında ilkokullardaki beden eğitimi, müzik, el işleri ve resim derslerinin özel alan eğitimi olmayan öğretmenler tarafindan 
yürütülmesinden kaynaklanan sorunların giderilmesi için 'tatil kursları' adıyla hizmetiçi eğitim verildiği görülmektedir (Öztürk, 2007). Bu uygulamaların varlığına karşın ülkemizde hizmetiçi eğitim programları resmi olarak ilk kez 1960 yılında sistemde yer almıştır. Günümüzde, öğretmenlere yönelik hizmetiçi eğitim etkinlikleri MEB Mesleki Gelişimi Destekleme ve İzleme Daire Başkanlığı tarafindan merkezi olarak planlanmakta ve yürütülmektedir. Ayrıca MEB, hizmetiçi eğitim uygulamalarında yaşanan sorunları çözmek, öğretmenlerin eğitim gereksinimlerini yerinde ve zamanında karşılamak, etkinlikleri daha etkili ve yaygın şekilde hayata geçirmek için taşra örgütlerine de hizmetiçi eğitim programları düzenleme yetkisi vermiştir (Bayram, 2010; Şahin, 1999). Son yıllarda, MEB ve özel kuruluşların işbirliğiyle hayata geçirilen projeler sayesinde (Abazaoğlu, 2014; Seferoğlu, 2004) hizmetiçi eğitimin etkin bir yapıya kavuşturulduğu söylenebilir.

Bu gelişmelere karşın alanyazın çalışmaları, ülkemizde hizmetiçi eğitim ile ilgili çeşitli sorunların yaşandığını göstermektedir. Araştırmalarda öne çıkan sonuçlardan biri öğretmenlerin etkinliklere katıl(a)mama sorunudur (European Commission, 2015). Bununla birlikte, etkinlik konularının öğretmenlerin ihtiyaç duyduğu kapsamda, uygun yöntem, teknik, araç ve gereç kullanılarak işlenmediği, dolayısı ile programda amaçlanan bilgi ve becerilerin katılımcılara kazandırılmadığı (OECD, 2010; Özavcı ve Çelikten, 2017; Şahin, 2012), konu sunumlarında anlatıma dayalı ve kuramsal ağırlıklı bir yaklaşım izlendiği ve uygulamaya yer verilmediği (Gökmenoğlu, 2012; Karaca, 2010; Özen, 2006), etkinlikler öncesinde ve esnasında katılımcı görüşlerinin alınmadığ1 (Kızılarslan, 2012; Uçar ve İpek, 2006) ve etkinliklere alınan kişilerin objektif kriterlere göre belirlenmediği (Çiftci, 2008; Şahin, 2012) görülmektedir. MEB tarafından yapılan çalışmalarda ise mesleki gelişime yönlendirmenin yetersiz olduğu, personel sayısının çok olması nedeniyle herkesin hizmetiçi eğitimlerden yeterince yararlanamadığı, hizmetiçi eğitimlerin verimliliği ile çalışanların motivasyon ve örgütsel bağlılık düzeylerinin beklenen yönde olmadığı (MEB, 2008, 2009, 2017) ortaya çıkmıştır.

Günümüzde öğrenme-öğretme anlayışı, öğrencinin özerkliğine ve öğretmenin öğrenme sürecini kolaylaştırıcı ve yönetici bir rol üstlenmesine doğru kaymıştır. Öğrenme ve öğretme, yeni teknolojilerle desteklenen, daha öğrenen merkezli ve daha esnek bir yapıya dönüşmüştür (Raud ve Orehhova, 2017). Mevcut dönüşüm, müzik eğitimini de doğrudan etkilemekte, müzik öğretmenlerinin sınıf içi öğretim süreçlerinde teknolojiyi etkin biçimde kullanmasını ve teknoloji destekli öğretim yöntemlerini tercih etmesini zorunlu kılmaktadır. Diğer taraftan Kalyoncu (2004) geleneksel müzik dersi resminin dönüşüm geçirmekte olduğunu, yeni hedef, içerik ve yöntem bilimsel gelişmelerin, müzik dersinden ve müzik öğretmeninden salt şarkı söyleyip çalgı çalma işleminin ötesinde de taleplerde bulunduğunu ve müzik öğretmeninin işlev alanının artık oldukça genişlediğini ifade etmektedir. Bu bağlamda, müzik öğretmenliği mesleğindeki en büyük zorluklardan biri öğretmenlerin müzik eğitimi alanındaki yeni uygulama ve yaklaşımlar konusunda güncel kalabilmeleridir (Clements, 2010). Hizmetiçi eğitim, müzik öğretmeninin bahsedilen beklentilere cevap verebilmesi ve mevcut dönüşüme uyum sağlaması için etkili bir uygulama yöntemidir. Ancak, hizmetiçi eğitim ile ilgili yaşanan sorunların müzik öğretmenliği mesleğinde de yaşandığı görülmektedir. Araştırma sonuçları, müzik öğretmenlerinin HİE etkiliklerine katılım oranlarının düşük olduğunu göstermektedir. Bu sorunun yanı sıra, öğretmenler hizmetiçi eğitim programlarını nicelik ve nitelik bakımından yetersiz bulmaktadır. Öğretmenler, müzik dersini planlama, uygulama ve değerlendirme, eğitim teknolojileri, müzik öğretim yöntem ve teknikleri, eşlik, besteleme, okul çalgıları ve eğitim müziği dağarı, okul, aile ve çevre ilişkisi konularında hizmetiçi eğitime ihtiyaç duymaktadır (Akdüz, 2006; Andırıcı, 2006; Çiftçi, 2008). Müzik öğretmenlerinin hizmetiçi eğitim ihtiyaçlarının genel olarak karşılanamadığı ve mesleki gelişimde sürekliliğin sağlanması için hizmetiçi eğitimde yeni yapılanmaya gidilmesi gerektiği (Çiftçi, 2008) ifade edilmektedir. Araştırma sonuçlarına dayanarak, müzik öğretmenlerinin hizmetiçi eğitime ihtiyaç duydukları ve katılma eğiliminde oldukları ancak bu beklenti ve eğilime karşın, öğretmenlerin etkinliklere katılma konusunda olumsuz bir tutum geliştirdikleri düşünülmektedir.

Hizmetiçi eğitimin başarısı, hedef kitle olan öğretmenlerin ihtiyaçlarının ve öğrenme özelliklerinin saptanmasına ve hizmetiçi eğitim etkinliklerinin planlanması, uygulanması ve değerlendirilmesiyle ilgili temel ilkelerin dikkate alınmasına bağlıdır (Guskey, 1991; Hakan ve diğerleri, 2011; O’Sullivan, 2000). Ancak müzik öğretmenlerine yönelik düzenlenen hizmetiçi eğitim programlarına ilişkin var olan güncel sorunlar, programları planlama sürecinde ihtiyaç belirleme ilkelerinin dikkate alınmadığını göstermektedir. Bu görüşler 1şı̆̆ında çalışmanın amacı, müzik öğretmenlerinin hizmetiçi eğitim etkinliklerine katılma durumlarını belirlemek ve beklentilerini ortaya koymaktır. Çalışmanın, müzik öğretmenliği mesleğinde mesleki gelişim sorununa dikkat çekmesi ve sunulan öneriler yoluyla katılım oranlarını olumlu yönde etkileyebilecek bazı planlamaların hayata 
geçirilmesine katkı sağlaması beklenmektedir. Araştırmada aşağıdaki sorulara cevap aranmıştır. Müzik öğretmenlerinin;

1. Milli Eğitim Bakanlığı ve İl Milli Eğitim Müdürlüğü tarafından düzenlenen hizmetiçi eğitim etkinliklerine katılma durumu nedir?

2. Cinsiyet, çalışılan kurum, lisansüstü eğitim ve mesleki deneyime göre hizmetiçi eğitim etkinliklerine katılma durumu nedir?

3. Katıldıkları hizmetiçi eğitim etkinliklerinin konuları nelerdir?

4. Hizmetiçi eğitim etkinliklerinin içeriğine ilişkin beklentileri nelerdir?

5. Hizmetiçi eğitim etkinliklerini planlama, uygulama ve değerlendirme süreçlerine ilişkin beklentileri nelerdir?

\section{Yöntem}

Nitel araştırma özelliği taşıyan bu çalışma tekil tarama modeline göre yapılandırılmıştır. Tarama modellerinin temel amac1, geçmişte ya da halen var olan bir durumu herhangi bir müdahalede bulunmadan ortaya çıarmak ve kendi koşulları içinde tanımlamaya çalışmaktır (Karasar, 2014). Bu araştırmada da, müzik öğretmenlerinin hizmetiçi eğitim etkinliklerine katılma durumu ve beklentileri öğretmen görüşleri üzerinden saptanmaya çalışılmıştır.

\section{Çalışma Grubu}

Tarama araştırmaları geniş grupları kapsar. Ancak pratikte araştırma konusunu oluşturan evrenin tümünün incelenmesi olanaksızdır. Bu nedenle veriler bir örneklemle yapılan alan araştırması yoluyla toplanır (Gökçe, 1992). Bu bağlamda, araştırmanın örneklemini, Tokat il merkezinde görevli ve devlet okullarında çalışan 48 müzik öğretmeni oluşturmaktadır. İlgili kurumdan, bu çalışma grubu için gerekli izinler alınmıştır. Çalışma grubunun kişisel özellikleri Tablo 1'de verilmiştir.

Tablo 1. Çalışma Grubunun Kişisel Özelliklere Göre Dağglımı

\begin{tabular}{|c|c|c|c|}
\hline Kişisel Özellikler & & f & $\%$ \\
\hline \multirow{2}{*}{ Cinsiyet } & Kadın & 24 & 50,0 \\
\hline & Erkek & 24 & 50,0 \\
\hline \multirow{4}{*}{ Çalışılan Kurum } & Ortaokul & 20 & 41,7 \\
\hline & Güzel Sanatlar Lisesi & 13 & 27,1 \\
\hline & Lise & 9 & 18,8 \\
\hline & Özel Eğitim Kurumu & 6 & 12,5 \\
\hline \multirow{2}{*}{ Lisansüstü Eğitim } & Var & 12 & 25,0 \\
\hline & Yok & 36 & 75,0 \\
\hline \multirow{4}{*}{ Çalışma Süresi } & $1-5 \mathrm{y} 1 \mathrm{l}$ & 6 & 12,5 \\
\hline & $6-10$ y1l & 17 & 35,4 \\
\hline & $11-15$ y1l & 17 & 35,4 \\
\hline & 16 ve üzeri yıl & 8 & 16,7 \\
\hline
\end{tabular}

Tablo 1'e göre öğretmenlerin \%50'si kadın, \%50'si erkektir. Aynı tabloya göre öğretmenlerin \%41,7 çoğunluğu ortaokullarda, \%27,1'i Güzel Sanatlar Lisesi'nde, \%18,8'i liselerde, \%12,5'i ise özel eğitim kurumlarında görevlidir. Diğer taraftan öğretmenlerin \%25'inin lisansüstü eğitim aldı̆̆ 1 , buna karşın $\% 75$ çoğunluğunun lisansüstü eğitim almadığı görülmektedir. Çalışma sürelerine göre öğretmenlerin \%12,5'i 1-5 yıl, \%35,4'ü 6-10 y1l, yine \%35,4’ü 11-15 y1l, \%16,7'si 16 ve üzeri y1l meslek tecrübesine sahiptir.

\section{Verilerin Toplanması}

Bu çalışmanın verileri görüşme tekniğiyle toplanmıştır. Bireylerin belli konulara ilişkin yaşantılarını, algılarını ve bunlara yüklediği ortak anlamları deşifre etmeyi amaçlayan betimsel çalışmaların en önemli veri toplama aracı görüşmedir. Bireysel ya da toplu yapılan görüşmeler sonucunda elde edilen deneyimler tanımlanır ve temalar ortaya çıkarılır (Patton, 2014). Çalışmanın verilerini elde etmek için kişisel bilgi formu ve standartlaştırılmış açık uçlu görüşme formu kullanılmıştır. Kişisel bilgi formunda; öğretmenlerin cinsiyeti, çalıştıkları kurum, lisansüstü eğitim durumları, çalışma süreleri, hizmetiçi eğitim etkinliklerine katılma durumları ve katıldıkları etkinliklerin 
konularını belirlemeye yönelik sorular bulunmaktadır. Görüşme formundaki sorular iki farklı yapıya sahiptir. Formda, öğretmenlerin hizmetiçi eğitimin içeriğine ve etkinlikleri planlanma, uygulama ve yürütme süreçlerine ilişkin beklentilerini ve gerekçelerini belirlemeye yönelik sıralamalı ve açık uçlu sorular yer almaktadır. Görüşme formunda yer alan sorulardan örnekler aşağıda verilmiştir.

Tablo 2a. Etkinliklerin İçeriğine İlișkin Beklentileri Belirlemeye Yönelik Hazırlanan Soru Örneği

\begin{tabular}{|c|c|c|c|}
\hline Beklenti Alanı & Soru & & Beklentiler \\
\hline \multirow{4}{*}{ Etkinliklerin İçeriği } & \multirow{3}{*}{\multicolumn{2}{|c|}{$\begin{array}{l}\text { Hizmetiçi eğitim etkinliklerinde hangi konuların yer almasını istersiniz? } \\
\text { (Önem sırasına göre belirtiniz!) }\end{array}$}} & 1 \\
\hline & & & 2 \\
\hline & & & 3 \\
\hline & \multicolumn{3}{|c|}{ Lütfen tercih sıralamanızın gerekçesini açıklayınız. } \\
\hline \multirow{2}{*}{\multicolumn{4}{|c|}{$\begin{array}{lll}\text { ablo 2b. Etkinliklerin Şekilsel Yapısına İlişkin Beklentileri Belirlemeye Yönelik Hazırlanan Soru Örneği } \\
\text { Beklenti Alanı } & \text { Açıklama } & \begin{array}{l}\text { Hizmetiçi eğitim etkinlikleri ne zaman } \\
\text { yapılmalıdır? }\end{array} \\
\end{array}$}} \\
\hline & & & \\
\hline \multirow{6}{*}{$\begin{array}{l}\text { Etkinliklerin } \\
\text { Planlanması, } \\
\text { Uygulanması ve } \\
\text { Değerlendirilmesi }\end{array}$} & \multirow{5}{*}{$\begin{array}{l}\text { Yandaki seçenekleri ihtiyaç önceliğinize göre 1-5 } \\
\text { arasında sıralayınız. (1 en öncelikli!) }\end{array}$} & \multicolumn{2}{|c|}{..... Yaz tatilinde } \\
\hline & & \multicolumn{2}{|c|}{ Ara (15) tatilde } \\
\hline & & \multicolumn{2}{|c|}{ Eğitim-öğretim zamanında } \\
\hline & & \multicolumn{2}{|c|}{ Seminer döneminde } \\
\hline & & \multicolumn{2}{|c|}{ Diğer (Lütfen açıklayınız!)......... } \\
\hline & \multicolumn{3}{|l|}{ Lütfen tercih sıralamanızın gerekçesini açıklayınız. } \\
\hline
\end{tabular}

\section{Verilerin Analizi}

Çalışma verileri, betimsel analiz tekniği kullanılarak çözümlenmiştir. Betimsel analiz daha çok, araştırmanın kavramsal yapısının önceden açık biçimde belirlendiği durumlarda kullanılır. Diğer taraftan nitel çalışmalarda yazılı biçimdeki verinin belirli bir düzeyde sayılara indirgenmesi mümkündür. Sayısal analiz, çalışma verilerinin sayılara veya rakamlara dökülmesidir. Nitel verinin sayısallaştırılmasının temel amacı; güvenirliği arttırmak, yanlılığı azaltmak, veriler arasında karşılaştırma yapmaya olanak vermek ve yapılan küçük ölçekli bir araştırmanın veya bir durum çalışması sonuçlarının daha sonra geniş bir örneklem üzerinden tekrar sınanmasına olanak sağlamaktır (Yıldırım ve Şimşek, 2006). Bu araştırmada, verilerin analizi için frekans ve yüzde hesaplamaları yapılmıştır.

\section{Geçerlik ve Güvenirlik}

Nitel araştırmalarda geçerlik, güvenirliği önemli ölçüde güven altına alır ve geçerliğe verilen önem aynı zamanda güvenirliği sağlamaya yönelik alınmış bir önlem olarak algılanmalıdır. Toplanan verilerin ayrıntılı olarak rapor edilmesi ve araştırmacının sonuçlara nasıl ulaştığını açıklaması nitel araştırmalarda, geçerliğin önemli ölçütleri arasında yer alır (Yıldırım ve Şimşek, 2006). Bu çalışmada geçerliği sağlamak için konu ile ilgili alan taraması yapılmış, kavramsal bir çerçeve oluşturulmuş ve görüşme formu kavramsal çerçeveye göre hazırlanmıştır. Görüşme formunun anlaşılırlığını ve çalışma amacına uygunluğunu belirlemek için eğitim bilimleri alanından iki uzmanın görüşlerine başvurulmuştur. Gelen dönütler doğrultusunda gerekli düzeltmeler yapılarak forma son şekli verilmiştir. Elde edilen veriler yazarlar tarafından düzenlenmiş, eşzamanlı analiz edilmiş ve daha sonra karşılaştırma yapılmıştır.

Veriler, bulgular kısmında sayısallaştırılarak ve tablolarla desteklenerek yorumlanmış, ayrıca yorumları güçlendirmek için öğretmenlere ait bazı görüşler doğrudan aktarılmıştır. Nitel çalışmalarda 'katılımcı teyidi' güvenirlik için önemli bir yöntemdir. Bu yaklaşım doğrultusunda, katılımcıların, diğer sorularda karşılı̆̆ bulunmayan ve konuyla ilgili olduğunu düşündükleri algılarını ve/veya deneyimleri aktarabilecekleri açık uçlu bir soruyla veri kaybını en aza indirerek güvenirliğin sağlanması amaçlanmıştır.

\section{Bulgular}

Bu bölümde, müzik öğretmenlerinin hizmetiçi eğitim etkinliklerine katılma durumu, düzenlenen etkinliklerin konuları ve öğretmenlerin hizmetiçi eğitimden beklentileri yer almaktadır. Bulguların sunumunda Milli Eğitim Bakanlığı için 'MEB', İl Milli Eğitim Müdürlüğü için 'IMEM' ve hizmetiçi eğitim için 'HİE' kısaltmaları kullanılmıştır. 
1. ve 2. Alt Probleme İlişkin Bulgular: Müzik öğretmenlerinin HíE etkinliklerine katılma durumu ve cinsiyet, çalışılan kurum, lisansüstü eğitim ve mesleki kıdem değişkenlerine göre dağılımı

Tablo 3. Müzik Öğretmenlerinin MEB ve İMEM Tarafından Düzenlenen Etkinliklere Katılma Durumuna İlişkin Dağılım

\begin{tabular}{lcccc}
\hline \multirow{2}{*}{ Katılma Durumu } & \multicolumn{2}{c}{ Evet } & \multicolumn{2}{c}{ Hayır } \\
\cline { 2 - 5 } & f & \% & f & \% \\
\hline MEB tarafindan düzenlenen etkinliklere katıldım & 7 & 14,6 & 41 & 85,4 \\
\hline İMEM tarafindan düzenlenen etkinliklere katıldım & 12 & 25,0 & 36 & 75,0 \\
\hline MEB ve/veya İMEM tarafindan düzenlenen etkinliklere katıldım & 17 & 35,4 & 31 & 64,6 \\
\hline
\end{tabular}

Tablo 3'e göre, müzik öğretmenlerinin \%14,6's1 MEB tarafından düzenlenen etkinliklere katılmış, \%85,4 çoğunluğu ise bakanlığın düzenlediği herhangi bir etkinliğe katılmamıştır. Yine öğretmenlerin \%25'inin İMEM tarafından düzenlenen etkinliklere katıldığı, \%75 çoğunluğunun ise müdürlüğün düzenlediği herhangi bir etkinliğe katılmadığı görülmektedir. Diğer taraftan öğretmenlerin \%35,4’ü MEB ve/veya İMEM tarafından düzenlenen etkinliklere katılmış olmasına karşın \%64,6'sı iki kurum tarafından düzenlenen herhangi bir etkinliğe katılmamıştır. Bulgular müzik öğretmenlerinin HİE etkinliklerine katılım oranlarının düşük olduğunu göstermektedir. Öğretmenlerin MEB yerine daha çok İMEM tarafından düzenlenen etkinliklere katılma eğiliminde oldukları söylenebilir. Bu eğilim ise İMEM etkinliklerinin, öğretmenlerin yaşadıkları şehirde düzenlenmesine ve kolay ulaşılır olmasına bağlanabilir.

Tablo 4. Katılma Durumunun Cinsiyet, Çalışılan Kurum, Lisansüstü Eğitim ve Mesleki Kıdem Özelliklerine Göre Dağılımı

\begin{tabular}{|c|c|c|c|c|c|}
\hline \multirow{2}{*}{ Kişisel Özellikler } & & \multicolumn{2}{|c|}{ Katılan } & \multicolumn{2}{|c|}{ Katılmayan } \\
\hline & & f & $\%$ & $\mathbf{f}$ & $\%$ \\
\hline \multirow{2}{*}{ Cinsiyet } & Kadın & 6 & 25,0 & 18 & 75,0 \\
\hline & Erkek & 11 & 45,8 & 13 & 54,2 \\
\hline \multirow{4}{*}{ Çalışılan Kurum } & İlköğretim & 7 & 40,0 & 13 & 60,0 \\
\hline & Ortaöğretim & 2 & 22,2 & 7 & 77,8 \\
\hline & Güzel Sanatlar Lisesi & 4 & 30,8 & 9 & 69,2 \\
\hline & Özel Eğitim Kurumu & 4 & 66,7 & 2 & 33,3 \\
\hline \multirow{2}{*}{ Lisansüstü Eğitim } & Var & 3 & 25,0 & 9 & 75,0 \\
\hline & Yok & 14 & 38,9 & 22 & 61,1 \\
\hline \multirow{4}{*}{ Mesleki Kıdem } & $1-5 \mathrm{y} 1 \mathrm{l}$ & 2 & 33,3 & 4 & 66,7 \\
\hline & $6-10$ yil & 3 & 17,6 & 14 & 82,4 \\
\hline & $11-15$ y1l & 9 & 52,9 & 8 & 47,1 \\
\hline & 16 ve üstü yıl & 3 & 37,5 & 5 & 62,5 \\
\hline
\end{tabular}

Tablo 4'e göre, kadın müzik öğretmenlerinin HİE etkinliklerine katılma oranı (\%25) erkek öğretmenlere göre $(\% 45,8)$ daha düşüktür. Çalışılan kuruma ilişkin bulgu incelendiğinde; orta öğretimde $(\% 22,2)$ ve Güzel Sanatlar Lisesi’nde $(\% 30,8)$ görevli müzik öğretmenlerinin katılma oranlarının ilköğretim (\%40) ve özel eğitim kurumlarında $(\% 66,7)$ görevli öğretmenlere göre daha düşük olduğu görülmektedir. Bu bulguda, özel eğitim kurumlarında görevli müzik öğretmenlerin katılma oranının $(\% 66,7)$ diğer kurumlarda görevli öğretmenlere göre daha yüksek olduğu dikkat çekmektedir. Diğer bir bulguya göre, lisansüstü eğitim alan ve almayan öğretmenlerin katılma oranlarında da fark vardır. Lisansüstü eğitim alan öğretmenlerin katılma oranı (\%25) lisansüstü eğitim almayan öğretmenlere göre $(\% 38,9)$ daha düşüktür. Mesleki kıdeme ilişkin bulguda ise 6-10 yıl arası tecrübeye sahip öğretmenlerin katılma oranının en düşük olduğu $(\% 17,6), 1-5$ yıl $(\% 33,3)$ ile 16 ve üstü yıl $(\% 37,5)$ tecrübeye sahip öğretmenlerin katılma oranlarının yine düşük ve birbirini yakın olduğu, 11-15 yıl tecrübeye sahip öğretmenlerin katılma oranının ise $(\% 52,9)$ diğer gruplara göre yüksek olduğu görülmektedir. Bu bulguya göre, mesleğin ilk 10 yılında etkinliklere katılımın düşük olduğu söylenebilir. Diğer taraftan 16 ve üstü yıl tecrübeli öğretmenlerin \%62,5'inin herhangi bir etkinliğe katılmaması ise düşündürücüdür. Bununla birlikte lisansüstü eğitim alan ancak hiçbir HİE etkiliğine katılmayan öğretmenlerin oranı da (\%75) dikkat çekmektedir. Bu durum, HİE etkinliklerinin yüksek lisans eğitimi alan öğretmenlerin ilgisini çekmediği veya beklentilerini karşılamadığ şeklinde yorumlanabilir.

\section{Alt Probleme İlişkin Bulgular: Müzik öğretmenlerinin katıldıkları HİE etkinliklerinin konusu}


Öztürk ve Öztürk

Tablo 5. Müzik Öğretmenlerinin En Son Katıldıkları Etkinliklerin Konularına Göre Dağılımı

\begin{tabular}{|c|c|c|c|}
\hline Düzenleyen Kurum & Konular & $\mathbf{f}$ & Toplam \\
\hline \multirow{5}{*}{ MEB } & Müzik dersi öğretim programı & 4 & \multirow{5}{*}{10} \\
\hline & Türk Halk Müziği jüri üyeliği & 2 & \\
\hline & Kitap inceleme & 2 & \\
\hline & Orff-Schulwerk eğitimi & 1 & \\
\hline & Üstün yetenekli öğrencilerde müzik eğitimi & 1 & \\
\hline \multirow{3}{*}{ İMEM } & Müzik dersi öğretim programı tanıtımı & 3 & \multirow{3}{*}{6} \\
\hline & Öğretmenlik mesleğinin sorunları ve çözüm yolları & 2 & \\
\hline & Orff-Schulwerk eğitimi & 1 & \\
\hline
\end{tabular}

Tablo 5'e göre, MEB ve MEM tarafından düzenlenen HİE etkinliklerinin konusu çoğunlukla ( $\mathrm{f}=4$ ve $\mathrm{f}=3$ ) müzik dersi öğretim programı tanıtımı amaçladır. Bunun dışında MEB'in, Türk halk müziği jüri üyeliği (f=2), kitap inceleme $(\mathrm{f}=2)$, Orff-Schulwerk eğitimi $(\mathrm{f}=1)$ ve üstün yetenekli öğrencilerde müzik eğitimi $(\mathrm{f}=1)$ konularında etkinlikler düzenlediği, İMEM'in ise öğretmenlik mesleğinin sorunları ve çözüm yolları ( $\mathrm{f}=2$ ) ve yine Orff-Schulwerk eğitimi ( $\mathrm{f}=1)$ konularında etkinlikler düzenlediği görülmektedir. Bulgulara göre HİE etkinliklerinin, MEB ve İMEM tarafından çoğunlukla güncellenen/yenilenen öğretim programlarını tanıtım amacıyla tercih edildiği, buna karşın öğretmenlerin mesleki ve kişisel gelişimlerine yönelik içeriklerin beklenen yönde planlanmadığg söylenebilir.

\section{4. ve 5. Alt Probleme İlişkin Bulgular: Müzik öğretmenlerinin HİE'den beklentileri}

Tablo 6. Etkinliklerin İçeriğine İlişkin Beklentilerin Dağılımı

\begin{tabular}{|c|c|c|}
\hline $\begin{array}{l}\text { İçerik } \\
\text { Beklentileri }\end{array}$ & f & Öğretmen Görüşlerinden Alıntılar \\
\hline $\begin{array}{l}\text { Müzik/Eğitim } \\
\text { Teknolojileri }\end{array}$ & 33 & $\begin{array}{l}\text { "Teknoloji, teknoloji, teknoloji, çă̆ teknoloji çağı! Öğrenciler teknolojik! Her konunun } \\
\text { mutlaka teknolojiyle ilişkilendirilmesi gerekir" }\end{array}$ \\
\hline $\begin{array}{l}\text { Müzik Öğretim } \\
\text { Yöntemleri }\end{array}$ & 30 & $\begin{array}{l}\text { "Kalabalık sınıflarda klasik müzik ögretim yöntemleri etkili olmuyor. Hizmetiçi } \\
\text { eğitimlerde farklı yöntemler tanıtılmalıdır. Ancak tanıtımlar örnek uygulamalarla } \\
\text { desteklenmelidir" }\end{array}$ \\
\hline $\begin{array}{l}\text { Okul Çalgıları ve } \\
\text { Eşlik }\end{array}$ & 28 & $\begin{array}{l}\text { "Şu an sıklıkla melodika öğretiyorum. Öğrettiğim bir şarklya eşlik yapmak istediğimde } \\
\text { armoni bilgim yeterli olmasına rağmen zorlanıyorum" } \\
\text { "Önemli gün ve haftalarla ilgili etkinliklerde program hazırlamakta zorlanıyorum. Farklı } \\
\text { çalgıların ögretimini yapılabilsem daha renkli etkinlikler hazırlayabilir" }\end{array}$ \\
\hline $\begin{array}{l}\text { Türk Müziği ve } \\
\text { Öğretimi }\end{array}$ & 24 & $\begin{array}{l}\text { "Makam öğretiminde zorlanıyorum çünkü kendim hakim değilim. Bir Türk müziği çalgısı } \\
\text { ögrenmek istiyorum" }\end{array}$ \\
\hline Rehberlik & 20 & $\begin{array}{l}\text { "Öğrenci profili çok farklı, kllık-klyafet serbestisi, kalabalık sinıflar ve aileden } \\
\text { kaynaklanan hem sinıf içi hem de sinıf dışı disiplin problemleri yaşılyoruz. Ögrencileri sınıfta } \\
\text { kontrol altında tutmak eskiye göre daha zor. Öğretmenler için etkili sinıf yönetimi, iletişim, } \\
\text { rehberlik vb. seminerler verilmeli" }\end{array}$ \\
\hline Kişisel gelişim & 18 & $\begin{array}{l}\text { "Mesleki gelişim sadece teorik algllanmamall, lisansüstü eğitime yönlendirici ve } \\
\text { bilgilendirici etkinlikler düzenlenmeli" } \\
\text { "Seminer konuları genellikle anlatıma dayalı oluyor, kişisel gelişimimizle ilgili konular } \\
\text { yer almıyor bu da ilgimi çekmiyor. Mesela etkili konuşma ve iletişim, yabancı dil, proje } \\
\text { geliştirme gibi etkinlikler düzenlenebilir" }\end{array}$ \\
\hline $\begin{array}{l}\text { Müzik Dersi } \\
\text { Ögretim } \\
\text { Programları }\end{array}$ & 4 & $\begin{array}{l}\text { "Öğretim programı benim için önemli bir kılavuz. Programa hakim olursam etkili bir ders } \\
\text { yürütebileceğimi düşünüyorum. Ayrıca programla ilgili son güncellemeden haberdar olmak } \\
\text { istiyorum" }\end{array}$ \\
\hline
\end{tabular}

Tablo 6'ya göre, müzik öğretmenleri etkinliklerde çoğunlukla (f=33) müzik/eğitim teknolojileri konularının yer almasını istemektedir. Bu talebi müzik öğretim yöntemleri ( $\mathrm{f}=30)$ ile okul çalgıları ve eşlik $(\mathrm{f}=28)$ konularındaki talepler izlemektedir. Bununla birlikte öğretmenler Türk müziği ve öğretimi (f=24) ile rehberlik ( $\mathrm{f}=20)$ konularında da etkinlik talep etmektedir. Beklentilerdeki genel eğilimin alan konularında yoğunlaştığ görülmektedir. Tabloda, öğretmenlerin müzik dersi öğretim programlarına ilişkin etkinlik talebi (f=4) yer almasına karşın diğer konu başlıklarıyla karşılaştırıldığında, program tanıtım amaçlı etkinliklerin çoğu öğretmen tarafından talep edilmediğini belirtmek gerekir. Bu durum, tablo 5'de de görüldüğü üzere, öğretmenlerin katıldıkları etkinliklerin çoğunlukla program tanıtım konularında yoğunlaşmasına bağlanabilir. 
Tablo 7. Etkinliklerin Planlanması, Yürütülmesi ve Değerlendirilmesine İlişkin Beklentilerin Dağılımı

\begin{tabular}{|c|c|c|c|}
\hline $\begin{array}{l}\text { Beklenti } \\
\text { Alanları } \\
\end{array}$ & Görüşler & f & Öğretmen Görüşlerinden Alıntılar \\
\hline \multirow{3}{*}{$\begin{array}{l}\text { Konu Belirleme } \\
\text { Yöntemi }\end{array}$} & Fikrim alınmalı & 42 & \multirow{3}{*}{$\begin{array}{l}\text { "Mesleğimde 12. yllım. } 4 \text { defa kursa katıldım ama kimse } \\
\text { gelip fikrimi sormadl. Nerde, ne zaman yapıldığı önemli } \\
\text { değil sadece beklentilerimin dikkate alındığı bir yaklaşım } \\
\text { veya yöntem bekliyorum" } \\
\text { "Etkinlik sayllarl çok az ve bence sıkıcı. Teknoloji } \\
\text { kullanımının yaygınlaştı̆̆ bu devirde bakanlık e-hizmetiçi } \\
\text { eğitim yöntemine odaklanmall" }\end{array}$} \\
\hline & Üniversiteler belirlemeli & 18 & \\
\hline & MEB/İMEM belirlemeli & 6 & \\
\hline \multirow{3}{*}{ Eğitimci(ler) } & $\begin{array}{l}\text { Üniversiteden öğretim } \\
\text { elemanları yürütmeli }\end{array}$ & 40 & \multirow{3}{*}{$\begin{array}{l}\text { "Üniversiteden gelen hocaların anlatımı daha farklı ve } \\
\text { eğlenceli oluyor" } \\
\text { "Program tanıtımını yapan formatör ögretmenin } \\
\text { programa hakim olduğunu düşünmüyorum" }\end{array}$} \\
\hline & $\begin{array}{l}\text { Üniversite ile MEB ortak } \\
\text { yürütmeli }\end{array}$ & 12 & \\
\hline & İMEM yürütmeli & 0 & \\
\hline \multirow{3}{*}{ Şehir } & Görev yerimde yapılmalı & 33 & \multirow{3}{*}{$\begin{array}{l}\text { "MEB'in maddi desteği kısıtll, başka bir şehre seminere } \\
\text { gittiğimde kendi bütçemden harcama yapıyorum. Bence } \\
\text { yolluk-yevmiye gibi bütçeler arttırılmalı veya görevli } \\
\text { bulunduğumuz şehirde yapılmal," }\end{array}$} \\
\hline & Deniz kenarında yapılmalı & 6 & \\
\hline & Büyükşehirde yapılmalı & & \\
\hline \multirow{3}{*}{ Zaman } & $\begin{array}{l}\text { Seminer döneminde } \\
\text { yapılmalı }\end{array}$ & 32 & \multirow{3}{*}{$\begin{array}{l}\text { "Tatil dönemindeki etkinliklerde insan konsantre } \\
\text { olamıyor. Bence seminer dönemleri hizmetiçi eğitim için çok } \\
\text { ideal. Bu dönemde aslında hiçbir şey yapmıyoruz. Seminer } \\
\text { döneminde yapılırsa daha verimli ve çok katılımlı olur" }\end{array}$} \\
\hline & Ders zaman 1 yapılmalı & & \\
\hline & Tatil zamanı yap1 & & \\
\hline \multirow{3}{*}{ Süre } & 1 hafta sürmeli & & \multirow{3}{*}{$\begin{array}{l}\text { "Ĕ̌gitim-öğretim zamanı haftada bir gün veya her dönem } \\
\text { bir hafta yapılsa daha etkili olur" }\end{array}$} \\
\hline & 5 gün sürmeli & & \\
\hline & gün s & 6 & \\
\hline \multirow{3}{*}{ Mekan } & Müzik sınıfında yapılmalı & 26 & \multirow{3}{*}{$\begin{array}{l}\text { "Öncelikle müzik alanında kurslar verilmeli ve etkinlikler } \\
\text { alana özel salonlarda gerçekleştirilmelidir" }\end{array}$} \\
\hline & Geniş salonlarda yapılmalı & & \\
\hline & Üniversitelerde yapılmalı & & \\
\hline \multirow{3}{*}{ Konaklama } & Kendi evimde kalmak isterim & & \multirow{3}{*}{$\begin{array}{l}\text { Yaşadı̆̆ım şehirde yapılırsa kendi evimde kalacă̆ım için } \\
\text { konaklama masrafim ve sorunum olmaz" }\end{array}$} \\
\hline & Otelde kalmak isterim & & \\
\hline & Misafirhanede kalmak isterim & 4 & \\
\hline \multirow{3}{*}{$\begin{array}{l}\text { Ölçme ve } \\
\text { Değerlendirme }\end{array}$} & Sinav olmamalı & 17 & \multirow{3}{*}{$\begin{array}{l}\text { "Kağıt ve kalemle değerlendirilince kendimi tuhaf } \\
\text { hissediyorum ve geriliyorum" } \\
\text { "Üniversitelerdeki akademik teşvik sistemi getirilmelidir. } \\
\text { Sinavlar modül üzerinden yapılmalı ve sinav sonucuna göre } \\
\text { teșvik verilmelidir" }\end{array}$} \\
\hline & Elektronik ortamda yapılmalı & 15 & \\
\hline & Sözlü yapılmalı & 10 & \\
\hline
\end{tabular}

Tablo 7'de yer alan ve sıklık durumunun en fazla olduğu tercih alanına göre sıralanarak sunulan bulgulara göre, müzik öğretmenlerin tamamına yakını HİE konularının kendileri tarafından belirlenmesini $(\mathrm{f}=42)$ ve konuların üniversiteden gelen öğretim elemanları tarafından sunulmasını $(\mathrm{f}=40)$ talep etmektedir. Diğer taraftan öğretmenlerin önemli bir çoğunluğu etkinliklerin görev yaptıkları şehirde ( $f=33$ ) ve seminer döneminde $(f=32)$ düzenlenmesi gerektiğini belirtmiştir. Bununla birlikte öğretmenlerin yarısından fazlası etkinliklerin 1 hafta sürmesini $(\mathrm{f}=28)$ ve müzik salonlarında/odalarında yapılmasını $(\mathrm{f}=26)$ beklemektedir. Tabloya göre öğretmenlerin yarısı etkinlik döneminde kendi evinde kalmak istemektedir $(\mathrm{f}=24)$. Son bulguda ise öğretmenlerin ölçme ve değerlendirme yapılmaması yönündeki görüşleri dikkat çekmektedir ( $\mathrm{f}=17)$. Değerlendirme yapılması gerektiğini düşünen öğretmenlerin önemli bir kısmı elektronik ortamı tercih ederken ( $\mathrm{f}=15)$ diğer bir kısmı sözlü yapılmasını $(\mathrm{f}=10)$ tercih etmektedir.

\section{Sonuç ve Öneriler}

Müzik öğretmenlerinin hizmetiçi eğitim (HİE) programlarına katılma durumunu ve beklentilerini saptamak amacıyla yürütülen bu çalışmada, öğretmenlerin etkinliklere katılım oranının düşük olduğu, etkinlikleri planlama, uygulama ve değerlendirme süreçlerine ilişkin çeşitli beklentilerinin bulunduğu sonucuna ulaşılmıştır. 
Araştırmada, müzik öğretmenlerinin \%64,6 çoğunluğunun Milli Eğitim Bakanlığı (MEB) veya İl Milli Eğitim Müdürlüğ̈ (IMEM) tarafindan düzenlenen herhangi bir mesleki gelişim etkinliğine katılmadığı belirlenmiştir. Bu sonuç, konuya ilişkin yapılan araştırma sonuçlarıyla örtüşmektedir. Çiftci (2008), Türkiye genelinde yaptı̆̆1 kapsamlı bir araştırmada müzik öğretmenlerinin \%65,7'sinin HïE etkinliklerine katılmadığını ortaya koymuştur. Benzer şekilde Andırıcı (2006), İstanbul'da görevli müzik öğretmenlerinin \%91,3'ünün, Akdüz (2006) ise Ankara ili örneklemi üzerinden yaptığı çalışmada yine müzik öğretmenlerinin \%40'ının branşlarıyla ilgili herhangi bir mesleki gelişim etkinliğine katılmadığını belirlemiştir. Benzer şekilde, güncel bir araştırmada, Türkiye'de sınıf öğretmenleri ve branş öğretmenlerinin mesleki gelişim etkinliklerine katılma oranlarının TIMSS'e katılan ülkeler ortalamasına göre oldukça düşük olduğu belirlenmiştir (MEB, 2016).

Araştırmanın diğer bir bulgusuna göre, MEB ve İMEM tarafından düzenlenen etkinlikler çoğunlukla öğretim programı tanıtımı amaçlıdır. Buna karşın müzik öğretmenleri öncelikle müzik alanında teknoloji kullanımı ve öğretim yöntemleri olmak üzere okul çalgıları ve eşlik, Türk müziği ve öğretimi, rehberlik ve kişisel gelişim konularında HİE talep etmektedir. Alanyazında var olan çalışma sonuçları ile bu çalışmada ortaya çıkan sonuçların örtüştüğü görülmektedir. Örneğin, MEB (2008) tarafindan yapılan bir araştırmada öğretmenlerin HïE'den beklentilerinin 68 konuda dağılım gösterdiği ve en düşük talebin 'değişen programların tanıtımı' olduğu görülmektedir. Yine ilgili kurum tarafından yapılan araştırmalara göre öğretmenlerin büyük çoğunluğu eğitimde yeni yaklaşımlar, yeni eğitim teknolojilerinin kullanımı, öğretme-öğrenme yöntem ve teknikleri, stresle başa çıkma yöntemleri, sınıf içi iletişim ve etkileşim, öğrenciyi tanıma teknikleri, sınıf yönetimi modelleri ve insan ilişkileri konularında etkinlikler düzenlenmesini beklemektedir (MEB, 2008, 2013, 2014). Müzik alanında yapılan araştırmalarda da öğretmenlerin öncelikli olarak müzik eğitiminde teknoloji ve müzik öğretim yöntemleri konularında HIE taleplerinin olduğu görülmektedir (Akdüz, 2006; Çiftci, 2008). Mevcut araştırma sonuçlarına dayanarak, müzik öğretmenlerinin HİE etkinliklerine beklenen oranda katılım sağlamadıkları, etkinlik konularının öğretmen beklentilerini karşılamadığı ve bu iki temel sorunun müzik öğretmenliği mesleğinde uzun süredir devam ettiği söylenebilir.

Çalışmanın son bulgusu, müzik öğretmenlerinin HİE etkinliklerini planlama, uygulama ve değerlendirme süreçleriyle ilgili beklentilerinin olduğunu göstermiştir. Müzik öğretmenlerinin tamamına yakını etkinlik konularının belirlenmesi aşamasında kendilerinden görüş alınmasını ve etkinliklerin alan uzmanı öğretim elemanları tarafından sunulmasını beklemektedir. Bununla birlikte öğretmenler etkinliklerin çalsştıkları şehirde düzenlenmesini, seminer dönemlerinde yapılmasını, bir hafta sürmesini, ölçme ve değerlendirme aşamasında sınav yapılmamasını veya sınavların elektronik ortamda yapılmasını talep etmektedir. Bu sonuçları alanyazında konuyla ilgili var olan çalışma sonuçlarıyla desteklemek mümkündür (Gökmenoğlu, 2012; Günbayı ve Taşdöğen, 2012; Özavcı ve Çelikten, 2017; Satmaz ve Gencel, 2016; Şahin, 2012). Bu araştırmanın yazarları, müzik öğretmenlerinin HİE programları planlanırken görüşlerinin alınması yönündeki beklentilerini önemli görmektedir. Çünkü, mesleki gelişim kurumsal olduğu kadar kişisel bir meseledir ve etkili olmak için birey tarafindan yönetilmelidir (Browell, 2000: aktaran Bush, 2007). Konuların öğretmenlerin ihtiyaçları doğrultusunda belirlenmesi, öğretmenlerin katılımını özendirecek, motivasyonlarını artıracak ve sınıflara taşınabilecek değişimlerin oluşmasını sağlayacaktır (Colwell, 1996/1997, aktaran, Bush; 2007).

Genel bir değerlendirme yapmak gerekirse; öğretmenler, meslek yaşamlarında çeşitli evrelerden geçerler ve her bir evrede farklı ilgi ve gereksinimlere sahiptirler. Mesleğe başladığı andan itibaren, öğretmenin ilgisi ve merakı belirli zamanlarda belirli noktalarda yoğunlaşır ve bu gibi yoğunlaşmalar farklı hizmetiçi eğitim modellerinin uygulanmasını gerekli kılar (Saban, 2000). Diğer taraftan öğretmenleri mesleki gelişime çeken şey, onların inançları ve güdülenmeleridir (Guskey, 2002; Şenel, 2014). Ancak mesleki gelişim programları, kuşkusuz birçok etken bulunmakla birlikte, özellikle öğretmenleri mesleki gelişim için motive eden etkenleri ve öğretmenlerdeki değişimin tipik olarak gerçekleştiği süreçleri dikkate almadığından dolayı çoğu zaman başarısız olmaktadır (Guskey, 1986). Gerek bu araştırmanın gerekse alanyazında yer alan diğer araştırmaların sonuçları, durumun ülkemiz için de geçerli olduğunu göstermektedir. Türkiye'de öğretmenler mesleki gelişime yeterince önem verilmediğini düşünmekte (Ceylan ve Özdemir, 2016) ve diğer branş öğretmenlerinde olduğu gibi müzik öğretmenlerinin beklentilerinin ilgili birimler tarafından yeterince dikkate alınmadığı anlaşılmaktadır. Bu durum, 'öğretmenlere yönelik sağlıklı, etkili ve düzenli bir hizmetiçi eğitim politikası mevcut değildir' (Budak ve Demirel, 2003; Karaca, 2010; Uçar ve İpek, 2006) ve 'hizmetiçi eğitim etkinliklerinin planlanması, uygulanması ve değerlendirilmesi ile ilgili yeni bir düzenlemeye gidilmesi kaçınılmaz hale gelmiştir' (Şahin, 1999) görüşlerini haklı çıkarmaktadır. Müzik öğretmenlerinin ihtiyaçları göz önüne alınmadan planlanan ve uygulama ile bağı 
olmayan mesleki gelişim programlarının etkili olamayacağı açıktır. Bu nedenle ilgili kurumlar tarafından HïE konusunda yaşanan sorunlara ivedi ve etkin biçimde müdahale edilmesi gerektiği ve mesleki gelişim konusunda radikal bir değiş̧ime ihtiyaç olduğu düşünülmektedir. Bu görüşler ışığında bazı öneriler sunulabilir.

Ülkemizde öğretmen kitlesi büyüktür ve mesleki gelişim için ayrılan bütçe kısıtlıdır (MEB, 2009; Seferoğlu, 2004). Bu durum HiE etkinliklerini planlama sürecindeki en önemli sorunlardan biridir. Diğer taraftan eğitim sistemimizde uzun yıllardır görev aldığı halde HİE etkinliklerine katılmayan müzik öğretmenlerinin olduğu da bilinmektedir. Bu nedenle üniversitelerin sürece dahil olması, MEB ve üniversite işbirliği ile "Hizmetiçi Eğitim Enstitüleri” kurulması ve eğitim fakültesi bulunan her üniversite tarafindan mesleki gelişim etkinlikleri düzenleme şartı getirilmesi önerilmektedir.

Öğretmenlerin, mesleki gelişimi önemsedikleri, hizmetiçi eğitimi kurumsal ve bireysel bakımdan kendilerine katk1 getiren bir etkinlik olarak gördükleri (Gültekin ve Çubukçu, 2008; Özen, 2006; Pepeler, Murat ve Akmençe, 2016; Sarıgöz, 2011; Satmaz ve Gencel, 2016), ancak HIE etkinliklerine ilişkin olumsuz tutuma sahip oldukları görülmektedir (Karasolak, Tanrıseven ve Konokman, 2013). Son yıllarda MEB tarafindan uygulanan modüller aracılığıyla öğretmenlerin HIE ihtiyaçları belirlenmekte ve öğretmenlerden etkinlikleri değerlendirmeleri istenmektedir. Bu uygulamanın doğru olduğu ancak yukarıdaki araştırma sonuçlarına dayanarak etkili olmadığı söylenebilir. Örgütsel bağlılığı artırmanın öncelikli yollarından birinin öğretmenlerin örgütten beklentilerinin karşılanma düzeyini artırmak (Türk Eğitim Derneği [TED], 2014) olduğu unutulmamalıdır. MEB Mesleki Gelişimi Destekleme ve İzleme Daire Başkanlığ tarafından daha işlevsel ve güçlü bir bilişim ağı kurularak bütün öğretmenlerin sisteme dahil edilmesi, talep ve değerlendirmelerin titizlikle takip ve analiz edilebileceği ayrı bir birim kurulması önerilmektedir.

Araştırmamızda müzik öğretmenlerinin MEM yerine İMEM tarafından düzenlenen etkinliklere katılma eğiliminde oldukları görülmüsstür. Mahalli düzeyde yapılan seminerlerin öğretmenlere daha çok katkı sağladığı ve seminerlerin başarısı ile İl Milli Eğitim Müdürlügü’nün hizmetiçi eğitime yaklaşımının yakından ilişkili olduğu bilinmektedir (Şahin, 2012). Bu anlamda, özellikle ekonomik etkenler düşünüldüğünde, etkinlikler öğretmenlerin görev yaptığı şehirde ve ilgili müdürlük tarafindan düzenlendiği takdirde katılım yüksek olabilir. Bu nedenle, 1993 yılında HİE ile ilgili mahalli yönetimlere verilen yetki alanının genişletilmesi, il bazında yapılan etkinliklerin raporlaştırılması ve ilgililerle paylaşılması önerilmektedir.

Müziğin doğasında ve öğretim süreçlerinde devinim ve eşlik vardır. Müzik öğretmenleri teorik sunumlar yerine sınıf içi öğretim süreçlerinde hayata geçirebilecekleri, uygulamaya dönük HïE etkinlikleri talep etmektedir. Diğer taraftan eğitim-öğretim başında ve sonunda yapılan seminerlerde zümre öğretmenleriyle birlikte yürütülen çalışmaların öğretmenler tarafından daha faydalı görüldüğü bilinmektedir (Pepeler ve diğerleri, 2016). Bu nedenle, müzik öğretmenliği programı bulunan üniversitelerde görevli öğretim elemanlarının müzik öğretmenleri için pratik ağırlıklı örnek uygulama etkinlikleri planlaması ve bu planlamaların seminer dönemlerinde aktif katılımlı yöntemlerle sunulması önerilmektedir.

Müzik öğretmenlerinin mesleki gelişim beklentilerine dikkat çeken güncel ve kapsamlı çalışmalara ihtiyaç olduğu düşünülmektedir. Alanyazında var olan az sayıdaki çalışma, bu konuda yapılacak olan araştırmalar için önemli çıkış noktaları sunmakta ve bu yönüyle değerli görülmektedir. Konuya ilgi duyan araştırmacıların, teorik çalışmaların yanı sıra, öğretmenlerin beklentilerine cevap verebilecek uygulamaya dönük projeler geliştirmeleri ve çalıştay gibi katılımlı HİE etkinlikleri düzenlemeleri önerilmektedir. 


\section{References}

Abazaoğlu, İ. (2014). Dünyada öğretmen yetiştirme programları ve öğretmenlere yönelik mesleki gelişim uygulamaları [Teacher training programs in world and professional development applications for teachers]. Turkish Studies-International Periodical for the Languages, Literature and History of Turkish or Turkic, 9(5), 1-46.

Akdüz, A. (2006). Illk ve orta dereceli okullarda görev yapan müzik öğretmenlerinin hizmet içi eğitim ihtiyaçlarının belirlenmesi [Determining the needs of music teachers who work in primary and secondary schools]. Master Thesis, Gazi University, Ankara, Turkey.

Altınışık, S. (1996). Hizmetiçi eğitim ve Türkiye'deki uygulama [In-service training and practice in Turkey]. Educational Administration: Theory and Practice, 2(3), 329-348.

Andırıcı, Ö. (2006). İlköğretimde müzik derslerinde kullanılan öğretim yöntemlerine ilişskin bir inceleme (İstanbul ili örneği) [A research on music teaching methods used in primary education]. Master Thesis, Uludağ University, Bursa, Turkey.

Avrupa Komisyonu/EACEA/Eurydice (2013). Avrupa'da öğretmenler ve okul liderlerine ilişkin temel veriler. 2013 Baskisı. Eurydice Raporu, Luxembourg: Publications Office of the European Union.

Azad, S. B., Tavakoli, M. \& Ketabi, S. (2017). Teachers' reflections on the practicality of English in-service courses in Iran. 3L: The Southeast Asian Journal of English Language Studies, 23(3), 97-107.

Bayram, D. (2010). Türkiye, ABD, Japonya, İngiltere ve Avustralya'da fen ve fizik öğretmenlerine yönelik mesleki gelişim programlarının karşılaş̧ırılması [The comparison of professional development programs for science and physics teachers in Turkey, the USA, Japan, England and Australia]. Doctoral Dissertation, Ankara University, Ankara, Turkey.

Budak, Y. \& Demirel, Ö. (2003). Öğretmenlerin hizmetiçi eğitim ihtiyacı [In-service training needs for teachers]. Educational Administration: Theory and Practice, 9(1), 62-81.

Bush, J. E. (2007). Importance of various professional development opportunities and workshop topics as determined by inservice music teachers. Journal of Music Teacher Education, 16(2), 10-18.

Ceylan, M. \& Özdemir, S. M. (2016). Türkiye ve İngiltere'deki öğretmenlerin sürekli mesleki gelişime ilişkin görüşlerinin ve katılım durumlarının incelenmesi [Turkish and English teachers' views on continuous professional development (CPD) and their participation status in CPD activities]. Krrlkkale University Journal of Social Science, 6(1), 397-417.

Çiftci, E. (2008). Türkiye'de Milli Eğitim Bakanlı̆̆ tarafindan müzik öğretmenlerine verilen hizmet içi eğitimin incelenmesi ve müzik öğretmenlerinin hizmet içi eğitim ihtiyaçlarının belirlenmesi [An analysis of education given to in-service music teachers by Ministry of National Education in Turkey and determining the needs for in-service training of music teachers]. Doctoral Dissertation, Gazi University, Ankara, Turkey.

Clements, A. C. (2010). Alternative approaches in music education: Case studies from the field (Preface), A. C. Clements (Ed.) Alternative approaches in music education: Case studies from the field (pp. 3-7), MENC: The National Association for Music Education, United Kingdom: R\&L Education Publishing.

Deneme, S. \& Çelik, H. (2016). The features of a standart INSET: Drawbacks in key components, In K. Dikilitaş \& İ. H. Erten (Ed.), Facilitating in-service teacher training for professional development (pp. 1-14), USA, IGI Global Publishing.

Dewey, J. (2004). Demokrasi ve eğitim [Democracy and education] (Tufan Göbekçin, trans.). Ankara: Yeryüzü Publishing.

Eğitim-Bir Sen [Eğitimciler Birliği Sendikası]. (2004). Öğretmen sorunları araştırması [The research on teacher problems]. Ankara: Eğitim-Bir Sen Publishing.

Ergun, M., Ergezer, B., Çevik, İ . \& Özdaş, A. (1999). Öğretmenlik mesleğine giriş [Introduction to teaching profession]. Ankara: Ocak Publishing.

European Commission/EACEA/Eurydice (2015). The teaching profession in Europe: Practices, perceptions, and policies. Eurydice Report, Luxembourg: Publications Office of the European Union.

Gökçe, B. (1992). Toplumsal bilimlerde araştırma (2. bs.) [Research in social sciences (2nd. ed.)]. Ankara: Savaş Publishing.

Gökmenoğlu, T. K. (2012). Teachers' reports of their in-service training needs and design preferences. Doctoral Dissertation, Middle East Technical University, Ankara, Turkey.

Guskey, T. R. (1986). Staff development and the process of teacher change. Educational Researcher,15(5), 5-12. 
Guskey, T. R. (1991). Enhancing the effectiveness of professional development programs. Journal of Educational and Psychological Consultation, 2(3), 239-247.

Guskey, T. R. (2002). Professional development and teacher change. Teachers and Teaching: Theory and Practice, 8(3/4), 381-391.

Gültekin, M. \& Çubukçu, Z. (2008). İlköğretim öğretmenlerinin hizmetiçi eğitime ilişkin görüşleri [Perceptions of primary school teachers about in-service training]. The Journal of Social Sciences, 19(10), 185-201.

Günbayı, İ. \& Taşdöğen, B. (2012). İlköğretim okullarında çalışan öğretmenlerin hizmet içi eğitim programları üzerine görüşleri: Bir Durum Çalışması [Compulsory school teachers' views on in-service education programs: A case study]. Journal of the Human and Science Researches Social, 1(3), 87-117.

Hakan, A. et al. (2011). İlköğretim ögretmenlerinin öğretmenlik mesleği genel yeterlikleri alanlarındaki hizmetiçi eğitim gereksinimleri [In-service training needs of primary school teachers in the field of teaching profession general competencies]. Eskişehir: Anadolu University Publishing.

Hugh, T. S. (2001). Transforming teacher education, T. Hugh et al. (Ed.), Transforming teacher education: Lessons in professional development (pp. 1-10), USA, Bergin \& Garvey Publishers.

Jan, T. U. \& Hameed, I. (2016). Comparison of in-service teacher training programme at University of Peshawar (UOP) and Gomal University (GU) D.I.KHAN. Gomal University Journal of Research, 32(2), 58-64.

Kalyoncu, N. (2004). Müzik öğretmeni yeterlikleri ve güncel müzik öğretmenliği lisans programı [Music teacher competencies and actual music teacher training bachelor program]. In Proceedings of Symposium on Music Teacher Training from Musiki Muallim Mektebi to present-day (1924-2004) 7-10 April 2004 (pp. 510-525). Süleyman Demirel University, Isparta, Turkey.

Karaca, A. (2010). İlköğretim okulu öğretmenlerinin hizmet içi eğitim programlarına ilişkin görüşleri (Mudurnu örneği) [Primary school teachers' opinions about in service training programs (Mudurnu case)]. Master Thesis, Abant İzzet Baysal University, Bolu, Turkey.

Karasar, N. (2014). Bilimsel araştırma yöntemleri (27. bs.) [Scientific research methods (27th. ed.)]. Ankara: Nobel Publishing.

Karasolak, K., Tanrıseven, I. \& Konokman, G. Y. (2013). Öğretmenlerin hizmetiçi eğitim etkinliklerine ilişkin tutumlarının belirlenmesi [Determining teachers' attitudes towards in-service education activities]. Kastamonu Education Journal, 21(3), 997-1010.

Kızılarslan, S. (2012). Almanca ögretmenlerinin hizmet içi eğitim hakkındaki görüşleri ve bir araştırma [Examination of opinions of German language teachers about in service training]. Master Thesis, Yeditepe University, İstanbul, Turkey.

Küçükahmet, L. (1998). Öğretim ilke ve yöntemleri (12. bs.) [Teaching principles and methods (12th. ed.)]. İstanbul: Alkım Publishing.

Küçükaydın, M. A., Sağır, Ş. U. \& Kösterelioğlu, İ. (2017). In-service training argumentation application for elementary school teachers: Pilot study. European Journal of Science and Mathematics Education, 5(2), 158-164.

MEB [Milli Eğitim Bakanlığı]. (1994). Milli Eğitim Bakanlı̆̆ Hizmetiçi Eğitim Yönetmeliği. Tebliğler Dergisi, 2419.

MEB [Milli Eğitim Bakanlığı]. (2008). Sinıf öğretmenlerinin hizmet içi eğitim ihtiyacının belirlenmesi. Eğitimi Araştırma ve Geliştirme Dairesi Başkanlığı (EARGED), Ankara: MEB Yayınları.

MEB [Milli Eğitim Bakanlığı]. (2009). MEB 2010-2014 stratejik planı. Ankara: MEB Yayınları.

MEB [Milli Eğitim Bakanlığı]. (2013). Hizmetiçi eğitim ihtiyacını belirleme anketi. Ankara: MEB Yayınları.

MEB [Milli Eğitim Bakanlığı]. (2014). Hizmetiçi eğitim ihtiyacını belirleme anketi genel değerlendirme sonuçları. Ankara: MEB Yayınları.

MEB [Milli Eğitim Bakanlığı]. (2016). TIMSS 2015 ulusal matematik ve fen bilimleri ön raporu - 4. ve 8. sinıflar. Ankara: MEB Yayınları.

MEB [Milli Eğitim Bakanlığı]. (2017). 2016 faaliyet raporu. Ankara: MEB Yayınları.

Nawab, A. (2017). What difference could in-service training make? Insights from a public school of Pakistan. Teacher Development, 21(1), 142-159. 
OECD [The Organisation for Economic Co-operation and Development]. (2010). TALIS technical report: Teaching and learning international survey. Paris: OECD Publishing.

OECD [The Organisation for Economic Co-operation and Development]. (2016). PISA 2015 results (Volume II): Policies and practices for successful schools. PISA, Paris: OECD Publishing.

O'Sullivan, M. C. (2000). Needs assessment for inset for unqualified primary teachers in Namibia: An effective model. Compare: A Journal of Comparative and International Education, 30(2), 211-234.

Özavcı, E. \& Çelikten, M. (2017). Öğretmen görüşlerine göre uzaktan hizmet içi eğitim uygulamalarında karşıllaşılan sorunlar ve çözüm önerileri [The problems encountered in distance teacher training programs and solutions they offer to those problems]. Turkish Journal of Educational Studies, 4(2), 39-76.

Özden, Y. (2010). Ĕgitimde yeni değerler (8. bs.) [New values in education (8th. ed.)]. Ankara: Pegem Publishing.

Özen, R. (2006). İlköğretim okulu öğretmenlerinin hizmetiçi eğitim programlarının etkilerine ilişkin görüşleri (Düzce ili örneği) [Perceptions of primary school teachers about the effect of inservice training (INSET) programs (A case study: Düzce)]. Bolu Abant İzet Baysal University Journal of Faculty of Education, 6(2), 141-160.

Öztürk, C. (2007). Atatürk devri ögrretmen yetiştirme politikası, (2. bs.) [Teacher training policy during Atatürk's period (2nd. ed.)]. Ankara: Türk Tarih Kurumu Publishing.

Patton, M. Q. (2014). Nitel araştırma ve değerlendirme yöntemleri [Qualitative research \& evaluation methods]. Mesut Bütün \& Selçuk Beşir Demir, trans.). Ankara: Pegem Akademi Publishing.

Pepeler, E., Murat, A. \& Akmençe, E. (2016). İlkokullarda hizmet içi eğitim seminerlerinin öğretmenlere yararlılığı (Elazı̆̆ ili örneği) [The benefits of in-service training seminars for primary school teachers (Elazı $\breve{g}$ sample)]. Journal of Research in Education and Teaching, 5(2), 168-176.

Phin, C. (2014). Teacher competence and teacher quality in Cambodia's educational context linked to in-service teacher training: An examination based on a questionnaire survey. International Journal of Educational Administration and Policy Studies, 6(4), 62-69.

Raud, N. \& Orehhova, O. (2017). In-service training of teachers of English as a foreign language in Estonia: Mapping of trends and opportunities. Problems of Education in the 21st Century, 75(2), 194-203.

TED [Türk Eğitim Derneği]. (2014). Öğretmen gözüyle öğretmenlik mesleği [Teacher profession from teacher eyes]. Ankara: TED Publishing.

Saban, A. (2000). Hizmet içi eğitimde yeni yaklaşımlar [New approaches in in-service training]. National Education, 145, 2530.

Sarıgöz, O. (2011). İlköğretim öğretmenlerinin hizmet içi eğitim faaliyetleri ile ilgili görüşlerinin değerlendirilmesi [Assessment of primary school teachers' notions about in service training activities]. In Proceedings of the 2nd International Conference on New Trends in Education and Their Implications 27-29 April 2011 (pp. 1021-1030). Antalya, Turkey.

Satmaz, İ. \& Gencel, E. (2016). Bilim sanat merkezlerinde görevlendirilen öğretmenlerin hizmet içi eğitim sorunu [Issue of inservice training of the teachers assigned in science and art centers]. Buca Faculty of Education Journal, 42, 59-73.

Seferoğlu, S. S. (2004). Öğretmen yeterlikleri ve mesleki gelişim [Teacher competencies and professional development (In Turkish)]. Education in Bright on Science and Mind, 58, 40-45.

Slingerland, M. et al. (2017). Development and optimisation of an in-service teacher training programme on motivational assessment in physical education. European Physical Education Review, 23(1), 91-109.

Şahin, İ. (2012). Connecting staff development to teacher improvement: A case study of an in-service teacher education program for English teachers. Doctoral Dissertation, Middle East Technical University, Ankara, Turkey.

Şahin, M. (1999). Milli Eğitim Bakanlığı hizmetiçi eğitim faaliyetlerinin geliştirilmesine yönelik öneriler [Suggestions for the improvement of Ministry of National Education in-service training activities]. Educational Administration: Theory and Practice, 5(2), 221-227.

Şenel, Ö. O. (2014). Müzik öğretmenliği lisans programı öğrencilerinin öğretmenliğe güdülenmeleri [The rates of motivation dynamics on music teaching as a profession among undergraduate level students of music education]. National Education, 201, 149-164. 
Uçar, R. \& İpek, C. (2006). İlköğretim okullarında görev yapan yönetici ve öğretmenlerin MEB hizmet içi eğitim uygulamalarına ilişkin görüşleri [The views of primary schools administrators and teachers about in-service training programs in the Turkish educational system]. YYU Journal of Education Faculty, 3(1), 34-53.

Yıldırım, A. \& Şimşek, H. (2006). Sosyal bilimlerde nitel araştırma yöntemleri (6. bs.) [Qualitative research methods in the social sciences (6th ed.)]. Ankara: Seçkin Publishing.

Yoo, S. S. \& Lee, J. M. (2014). In-service education and training for teachers in Korea and the role of the private sector from 1945 to 1970s. The Asia-Pacific Education Researcher, 23(3), 413-424. 